\title{
Do early trends in oak barrens fire treatment predict later outcomes? Insights from three decades of vegetation monitoring
}

John B. Taft

\begin{abstract}
Background: Vegetation structure, species diversity, and composition have been monitored at a fire-treatment and a fire-free control unit of a dry oak barrens and woodland complex in southern Illinois, USA, over a 29-year period and five burns. The restoration hypothesis is that fire management would result in different trends for vegetation parameters of conservation interest between fire treatment and control units, that before-after differences would be greater with fire management, and that early trends provide a reliable predictor for later outcomes. This study examines effectiveness of management in achieving restoration goals and uses response to the first two burns and monitoring results over the first seven years as an estimation period to test whether early trends with fire treatment are a reliable predictor for outcomes following three additional burns over the following 22 years.

Results: Trends differed between fire-treatment and control units for all parameters measured, and before-after differences were greater at the fire treatment unit. However, trends at the fire-treatment unit during the estimation period were a poor predictor of later outcomes. Tree density and basal area declined more than expected while ground-layer species density, richness, diversity, and percent cover did not keep pace with expectations of increase. Trends at the control unit were more predictable; however, tree basal area declined more than expected, possibly due to an outbreak of rapid white oak mortality disease, and decline of ground-layer species density was less than predicted from the early estimation period.
\end{abstract}

Conclusions: Results suggested that fire alone can be effective at restoring woodland and barrens natural areas and that a fire return interval of about every four years would be optimal for maintaining composition and diversity in this specific oak barrens habitat. However, burns followed immediately by severe drought possibly can have negative interactions, resulting in declines of ground-layer species diversity.

Keywords: forecast analysis, plant functional groups, profile analysis, restoration, savanna, species diversity, woodland

Correspondence: jtaft@illinois.edu

Illinois Natural History Survey, Prairie Research Institute, University of Illinois,

1816 S. Oak Street, Champaign, Illinois 61820, USA

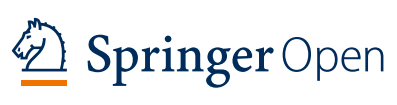

(c) The Author(s). 2020 Open Access This article is licensed under a Creative Commons Attribution 4.0 International License, which permits use, sharing, adaptation, distribution and reproduction in any medium or format, as long as you give appropriate credit to the original author(s) and the source, provide a link to the Creative Commons licence, and indicate if changes were made. The images or other third party material in this article are included in the article's Creative Commons licence, unless indicated otherwise in a credit line to the material. If material is not included in the article's Creative Commons licence and your intended use is not permitted by statutory regulation or exceeds the permitted use, you will need to obtain permission directly from the copyright holder. To view a copy of this licence, visit http://creativecommons.org/licenses/by/4.0/. 


\section{Resumen}

Antedecentes: La estructura de la vegetación, la diversidad y composición de especies fueron monitoreados en un tratamiento de fuego y en una unidad de control (sin fuego), en un complejo que incluyó bosques secos y abiertos de roble-praderas (dry oak barrens) y bosques de altura en el sur de Illinois, EEUU, por un período de 29 años y con cinco quemas. La hipótesis de restauración es que el manejo del fuego resulta en diferentes tendencias en parámetros de vegetación de interés de conservación entre los tratamientos de fuego y la unidad de control; que las diferencias entre el antes y el después van a ser mayores con el manejo del fuego, y que las tendencias iniciales proveen de un predictor confiable de resultados posteriores. Este estudio examina la efectividad del manejo para alcanzar metas de restauración y usa las respuestas a las dos primeras quemas y monitorea los resultados sobre los siete primeros años como un período de estimación, para probar si las primeras tendencias de tratamientos de fuego son un predictor confiable para los resultados luego de tres quemas adicionales en los siguientes 22 años.

Resultados: Las tendencias difirieron entre las unidades de tratamiento del fuego y el control para todos los parámetros medidos, y las diferencias entre el antes y el después de los tratamientos fue mayor en la unidad de tratamiento de fuego. Sin embargo, las tendencias en la unidad de tratamiento del fuego durante el periodo de estimación fueron un predictor pobre de resultados posteriores. La densidad de árboles y el área basal decrecieron más de lo esperado mientras que la densidad de especies a nivel del suelo, su riqueza, diversidad y porcentaje de cobertura no se tradujo en expectativas de incremento. Las tendencias en la unidad de control fueron más predecibles; sin embargo, el área basal de árboles declinó más de lo esperado, posiblemente debido a un rápido estallido de la enfermedad de mortalidad blanca del roble, y la declinación en la densidad de las especies rastreras fue menor que la predicha en el primer período de estimación.

Conclusiones: Los resultados sugieren que el fuego puede ser efectivo en restaurar bosques secos y abiertos de roble-praderas y mésicos de altura, y que intervalos de fuego cada cuatro años pueden ser óptimos para mantener la composición y diversidad en este hábitat particular de bosques secos de roble-praderas y bosques de altura. Sin embargo, las quemas seguidas inmediatamente por sequías severas posiblemente tengan interacciones negativas, resultando en una declinación en la diversidad de especies rastreras.

\section{Abbreviations}

DBH:

FSB:

GCB:

MANOVA: ANOVA:
Diameter at Breast Height

Forest Service Barrens

Gibbons Creek Barrens

Multivariate ANalysis Of VAriance ANalysis Of VAriance

\section{Background}

Savannas and open woodlands formerly were widespread in North America (Anderson 1983; Dey and Kabrick 2015); however, through habitat loss and degradation following Euro-American settlement, these biodiverse ecosystems have become among the most endangered (Curtis 1959; Nuzzo 1986; Noss et al. 1995). Classifications vary, but savannas in general are more open than woodlands; combining savannas and woodlands, canopy coverage ranges up to $80 \%$, with basal area in the midwestern United States ranging from $4.5 \mathrm{~m}^{2} \mathrm{ha}^{-1}$ (particularly on sandy soils) to $28.7 \mathrm{~m}^{2} \mathrm{ha}^{-1}$, with contemporary tree densities ranging from 165 to 1384 trees $^{-1}$ (Taft 1997). Dominant canopy species include several oaks (e.g., Quercus alba L., Q. stellata Wangh., Q. macrocarpa Michx., Q. velutina Lam.); however, the greatest floristic diversity in these ecosystems resides in the ground layer, composed

predominantly of relatively shade-intolerant species including warm-season $\left(\mathrm{C}_{4}\right)$ grasses such as Schizachyrium scoparium (Michx.) Nash. (Taft 1997).

Fire is recognized as essential for the restoration and maintenance of habitat structure, species composition, and diversity in oak-dominated savanna and woodland ecosystems (Curtis 1959; Anderson 1983; Abrams 1992; Dey and Kabrick 2015). Monitoring fire effects is a vital step in adaptive management of biological resources, with data on vegetation structure and composition often utilized for performance standards. However, detailed quantitative species-level monitoring is time consuming, requires specialized expertise, and, consequently, in many cases, captures data only from early periods of a fire-management program (e.g., Taft 2003; Hutchinson et al. 2005; Glasgow and Matlack 2007). Are trends from these early stages predictive of later outcomes for vegetation parameters of conservation interest? If not, in what ways do outcomes differ from expectations?

This study examines a 29-year record (1989 to 2017) from fire-treatment and fire-free control units in a southern Illinois, USA, oak-woodland complex, with a focus on a type of oak savanna known regionally as oak barrens (Hutchison 1994). Five burns were conducted during the study period. Vegetation was monitored nearly annually 
during years 1 to 7, and periodically afterwards. The control unit occurred on US Forest Service property adjacent to the fire-treatment unit and was slated for fire management ending its utility as a fire-free reference, which prompted this analysis. Oak barrens are characterized as having savanna to open woodland overstory structure and a mixture of prairie, savanna, and woodland species in the ground layer, and are generally found persisting on sites with shallow, infertile soils and southerly exposures (Heikens and Robertson 1995). Harsh environmental conditions in dry barrens have resulted in a degree of stability during periods of fire absence, permitting novel insights into restoring savanna and woodland ecosystems because, compared to habitats with fewer abiotic limitations to forest development, they retain some compositional and structural aspects presumably similar to conditions prior to widespread fire suppression following Euro-American settlement (Taft 1997). Thus, examining fire responses in such relatively undergraded natural areas that retain a rich diversity of native species particularly can contribute to establishing benchmarks and performance standards for evaluating the capacity of prescribed fire as a management tool in habitat restoration and maintenance.

Habitats such as dry oak barrens that are rich in species exist in intermediate positions along the grasslandforest continuum where strong feedback interactions between overstory canopy cover and ground-layer patch dynamics have been demonstrated (Scholes and Archer 1997). For example, canopies from woody plants intercept precipitation and solar radiation, contributing to heterogeneous patchwork mosaics of ground-layer species (Breshears 2006; Peterson and Reich 2008). Light availability has long been recognized as a limiting factor for species richness and cover in midwestern US savanna habitats (Bray 1958; Leach and Givnish 1999). Shaded patches provide novel niches for species that, while typically supporting lower alpha diversity compared to openings, contribute to increases in beta and gamma diversity (sensu Whittaker 1975). If, however, during extended fire-free intervals these patches coalesce, we can expect a decline in diversity at all spatial scales. This pattern forms the basis for the species attrition hypothesis for savanna and woodland communities (Taft 2009) that suggests that, during this process of community disassembly, an inverse relationship between overstory structure and ground-layer diversity can signal a promising restoration opportunity since, evidently, shade-intolerant species remain in the community, albeit with declining populations.

Vegetation parameters examined over the course of the study included aspects of overstory and ground-layer structure and composition (i.e., tree density, basal area, shrub-sapling density, ground-layer species density, richness, diversity, dominance, percent cover, and functional group composition). Examining outcomes from these parameters between fire treatment and fire-free control units provided a framework for testing a barrens (savanna) restoration hypothesis that reintroducing periodic fire can improve community structure by reducing woody encroachment and, consequently, facilitate promotion and maintenance of diversity among species appropriate for the habitat.

Presently, no other similar dataset exists for oakwoodland or barrens habitats in the Shawnee Section of the Interior Low Plateau Province of the Central Hardwoods Region, an area that extends from unglaciated sections of southern Illinois to southwestern Indiana and northwestern Kentucky, USA (Flint 1928; Hicks Jr. 1998). Anderson and Schwegman (1991) examined fire effects in a mesic barrens community in southern Illinois, following trends from four burns in rapid succession and again 15 years after last burn, although without a fire-free reference in the study design. Long-term fire effects in mixed-oak forests have been examined elsewhere in the eastern United States, with an emphasis on oak regeneration dynamics (reviewed by Brose et al. 2006), including within the Central Hardwoods Forest Region of southern Ohio, USA (Iverson et al. 2017), and the Missouri Ozarks, USA (Knapp et al. 2017). Longterm fire response studies in the Central Hardwoods Region that also included aspects of ground layer are scarce (Hutchinson 2006). Short-term studies have been carried out in southern Ohio (Hutchinson et al. 2005; Glasgow and Matlack 2007); studies examining longerterm trends have been conducted in nearby regions including northern Illinois (Bowles et al. 2007), central Tennessee, USA (DeSelm et al. 1991), and southeastern Minnesota, USA (White 1983; Tester 1989; Peterson et al. 2007). In general, these studies have shown that repeated burning affects the overstory by reducing the density of small-diameter stems, and only after prolonged repeated burning is tree basal area diminished. Ground-layer responses often include an increase in species richness, but the magnitude seems to hinge on what species persist aboveground and in the seed bank during oftentimes extended fire-free intervals prior to management. Studies combining thinning and burning treatments over short to intermediate time frames ( 4 to $19 \mathrm{yr}$ ) have been carried out in southern Ohio (Iverson et al. 2017), eastern Tennessee (Vander Yacht et al. 2017), southern Michigan (Bassett et al. 2020), and northern Illinois (Bowles et al. 2017) with similar results but with accelerated responses in the overstory and ground layer due to more rapid canopy thinning.

In the current study, based on the barrens restoration hypothesis, it was expected that fire management would reduce stem density in overstory and shrub-sapling strata, and that diversity and percent cover in the ground 
layer would increase. Previous findings following two burns indicated that fire had yet to significantly reduce canopy stem density but had a greater effect in reducing stem density in the smaller-diameter shrub-sapling stratum (Taft 2003). Presumably, severe cambial damage had yet to occur on larger trees with thicker bark. Early trends in the ground layer included increased species diversity and percent cover. However, because characteristic $\mathrm{C}_{4}$ grasses have been shown to increase with fire in tallgrass prairie (Collins and Gibson 1990) but had yet to do so after early phases in this study (Taft 2003), importance of these species was expected to increase under continued fire management. Expectations with fire absence, according to the species attrition hypothesis, were gradual increase in overstory stem density and declining ground layer diversity and cover. Consequently, it was expected that, after 29 years and five burns, trends among all overstory and ground-layer parameters at the fire-treatment and control units would have divergent profiles, and that before-after differences would be greatest at the firetreatment unit. Furthermore, relevant to evaluating the monitoring effort, it needs to be determined if early trends reliably predict later outcomes. Hence, research questions in this study were: (1) are trends between treatment and control units parallel or divergent over time?; (2) if so, are before-after differences among parameters greater at the treatment unit compared to control unit?; and (3) are forecasts generated from early trends (years 1 to 7 ) predictive of later outcomes? In addition, changes in species and functional group composition are examined for further evidence of habitat restoration with fire treatment.

\section{Methods}

\section{Study site}

Vegetation sample plots for both the fire-treatment and control units occurred within the Gibbons Creek Barrens Natural Area in Pope County, Illinois, USA (latitude: $37.5894^{\circ}$, longitude: $-88.4478^{\circ}$ ), a 111 ha unit divided in ownership between the Illinois Department of Natural Resources (Gibbons Creek Barrens Land and Water Reserve; GCB) and the Shawnee National Forest (Gibbons Creek Ecological Area, Forest Service Barrens; FSB). The oak barrens habitat in the natural area occurs as localized remnants within a matrix of dry to dry-mesic oak woodland. The best expression of the habitat (Fig. 1) and the target of this research are areas that are considered to be among the best examples remaining in Illinois (Illinois Natural Heritage Database; https://www2.illinois. gov/dnr/conservation/NaturalHeritage/Pages/NaturalHeritageDatabase.aspx). Dominant overstory species were post oak (Quercus stellata), winged elm (Ulmus alata Michx.), and hickories (Carya glabra [Mill.] Sweet, C. ovalis [Wangenh.] Sarg., and C. texana Buckl.). Ulmus alata was the dominant species in the shrub-sapling stratum. Ground-layer species that ranked among the

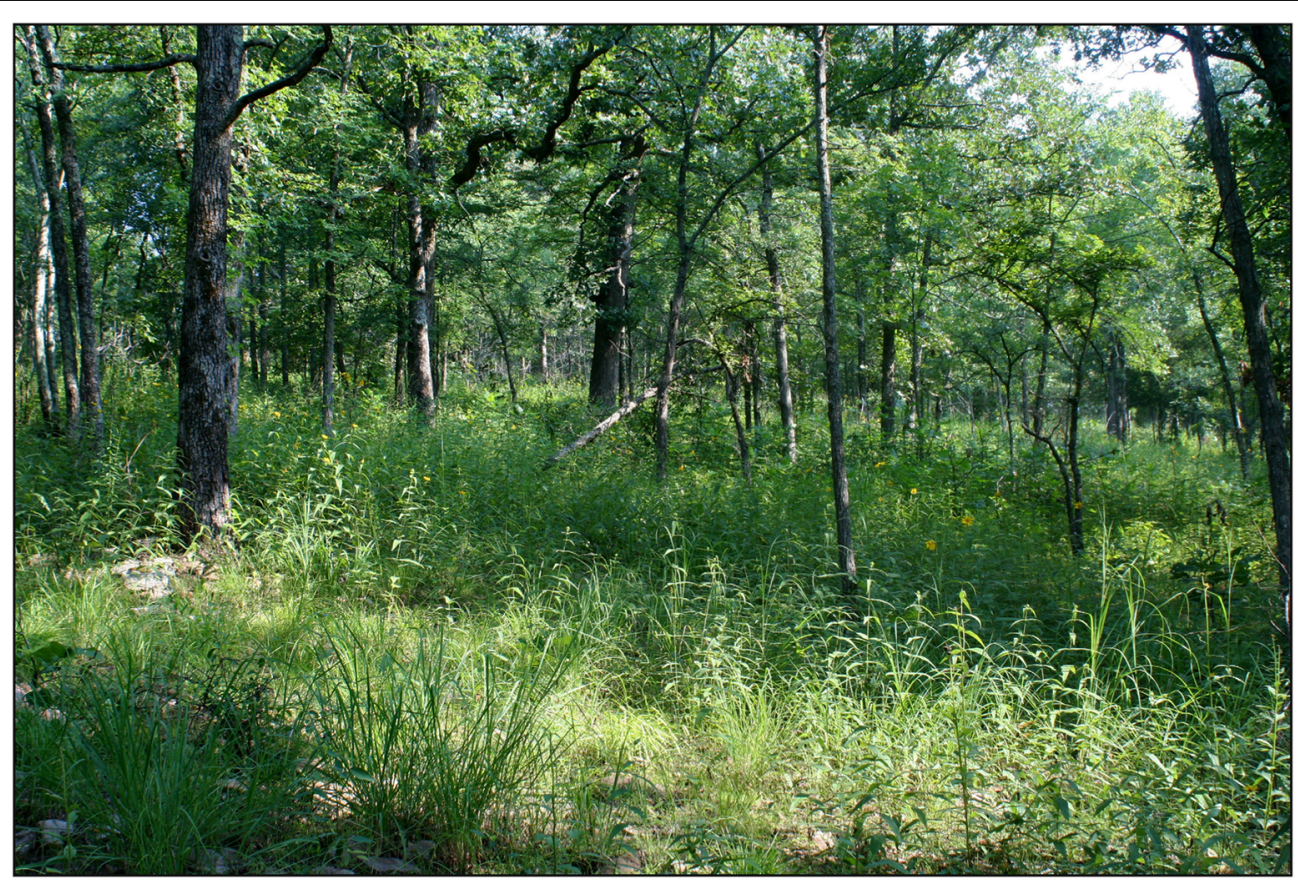

Fig. 1 Dry barrens community at the fire-treatment unit of Gibbons Creek Barrens Natural Area, Pope County, Illinois, USA. Photograph taken on 27 June 2006 following four burns at the peak levels of species diversity and structural stability recorded during the 1989 to 2017 time period. Photograph by John B. Taft 
dominants during the study included Schizachyrium scoparium, Dichanthelium laxiflorum (Lam.) Gould, D. linearifolium (Scribn.) Gould, Danthonia spicata (L.) Roem. \& Schultes, Carex albicans Willd. ex Spreng., Helianthus divaricatus L., Potentilla simplex Michx., and Amphicarpaea bracteata (L.) Fern. Study site characteristics and species composition and structure have been described previously in greater detail (Taft and Solecki 2002; Taft 2003).

\section{Treatment and vegetation sampling procedures}

All fire treatments except the first (burn date: 27 November 1989) occurred during the late dormant season for southern Illinois (16 March 1994, 3 April 1997, 2 March 2006, and 19 March 2010). Vegetation was sampled eight to nine times during the study period (trees were not measured in 1993) with a stratifiedrandom design using 0.05 ha circular plots for overstory ( $\geq 5 \mathrm{~cm}$ diameter at breast height $[\mathrm{DBH}])$ trees $(n=15$ at GCB; $n=8$ at FSB) with nested plots for the shrub-sapling (stems $<5 \mathrm{~cm} \mathrm{DBH},>50 \mathrm{~cm}$ in height) stratum $\left(50 \mathrm{~m}^{2}\right.$ circular plot) and ground-layer (all herbaceous species and woody plants $<50 \mathrm{~cm}$ ) stratum (twelve $0.25 \mathrm{~m}^{2}$ quadrats). Plots were centrally marked with metal posts for precise repeated sampling. All samples were recorded from late June through July, a period of maximum species richness in southern Illinois, when early- and late-developing species can be accurately identified. Ground-layer species abundance for most analyses was based on percent cover, determined by taking the midpoint of a modified Daubenmire cover-class scale $(1=0.5 \%, 2=3 \%, 3=15 \%, 4=$ $37.5 \%, 5=62.5 \%, 6=85 \%$, and $7=97.5 \%$; Daubenmire 1959). Rank order of species importance was based on importance value (IV $200=$ sum of relative frequency and relative cover). Parameters of species diversity examined in this study included species density (species per $0.25 \mathrm{~m}^{2}$ quadrat), species richness (species number recorded in 12 quadrats nested within each tree plot), the ShannonWeiner index of species diversity $\left(\mathrm{H}^{\prime}\right)$, and Simpson's dominance index (C; Whittaker 1975). The sample design and vegetation parameters were previously described in greater detail (Taft and Solecki 2002).

Reliable estimates of overstory canopy cover, commencing in 2013 and repeated in 2017, were determined using digital photography with a hemi-view lens oriented vertically in the plot center on a tripod $50 \mathrm{~cm}$ above the ground, the image narrowed to the approximate plot area with a lens tube. Percent visible sky was calculated from these images using HemiView Canopy Analysis Software, version 2.1 (Delta-T Devices, Ltd., Cambridge, England, United Kingdom). Each image was classified to accurately depict canopy cover by adjusting the contrast threshold display in comparison to continuous tone images (this procedure avoids tabulating clouds, for example, as canopy).

\section{Experimental design}

Because this study utilizes pre-treatment baseline data and an untreated control unit, elements of the analysis incorporate a Before-After-Control-Impact (BACI) design (Stewart-Oaten et al. 1986). The BACI design is strengthened by the use of a fire-free reference that is similar in structure and composition to the treatment site (Rasmussen et al. 1993), as was the case in this study (Taft and Solecki 2002), and by utilizing between-year contrast differences as response variables among treatment and control samples (van Mantgem et al. 2001). Aspects of the experimental design pertaining to pseudoreplication are addressed in the following section. It is anticipated that the longitudinal extent, precise vegetation sample design, and study questions have broad relevance and reinforce the need for long-term monitoring at similar study sites to provide more generalizable conclusions about fire effects in oak-woodland habitats of the Central Hardwoods Region.

\section{Data preparation, analysis, and statistical procedures}

Trends for gamma diversity were described across all treatment units to address restoration of this broader aspect of biodiversity. The data were based on total species number recorded for each period in the ground-layer samples. Floristic integrity at the site level for both units was tracked using the mean coefficient of conservatism (Taft et al. 1997), an index found to be robust for qualitative assessments of species composition (Taft et al. 2006; Matthews et al. 2016). Similarity of before-after species composition at fire treatment and control units was measure with Sørensen's coefficient of similarity (Mueller-Doombois and Ellenberg 1974). All statistical analyses were conducted with IBM SPSS version 26 (IBM SPSS 2019) and PERMANOVA+ for Primer-E version 7 (Anderson et al. 2008).

Question 1. I used profile analysis (IBM SPSS 2019) to determine whether response curves for vegetation parameters were equal between treatment and control units based on a generalized linear mixed model repeated measures of the between-year contrast differences analyzed simultaneously with MANOVA. The interaction between the within-subjects factor (time; i.e., year) and between-subject factors (treatment types; i.e., burn, control) is the major focus for profile analysis and the test of parallelism (von Ende 1993). The null expectation is a parallel response over time. With exception of the data property of circularity (von Ende 1993), expectations for ANOVA apply to MANOVA, including sample independence, normality, and equality of error variances and co-variance matrices (Scheiner 1993). Data in this study violate many of these assumptions. Independence was lacking in 
the application of the fire treatments because the needs for effective habitat management at GCB took precedence over improved experimental design that would have been gained by applying fire treatments individually to treatment plots. Consequently, statistical inference beyond these sites introduces risks of Type I statistical errors associated with pseudoreplication (Hulbert 1984). Each burn was applied at the landscape scale and characterized as low to intermediate intensity with heterogeneity across the treatment site produced by varying vegetation structure. Smallscale experimental burns at GCB, such as at the scale of tree plots, may have yielded improved statistical design but possibly less realistic effects compared with the heterogeneous landscape burns.

Although most data were normally distributed according to Shapiro-Wilk tests (Shapiro and Wilk 1965), with some parameters at either the treatment or control units one to three years from the eight- to nineyear sample sequence (out of a combined 16 to 18 total data series for each parameter) were non-normal with evident non-linear trends among residuals. Efforts at data transformation had limited success or, due to different scales in some transformations within data series, were undesirable; consequently, the mixed model profile analyses were run on mostly untransformed, predominately normally distributed data (shrub-sapling density was successfully transformed taking the square root). The MANOVA test statistic Pillai's trace was used for the test of parallelism since it is robust against violations in variance-covariance structure (Scheiner 1993). Between-year contrasts were examined using repeated measures one-way ANOVA as post-hoc tests to identify significant between-year contrast differences with the Bonferroni adjustment to alpha (Abdi 2007) according to the number of contrasts examined ( $n=7$ for tree density and basal area; $n=8$ for all other parameters).

Question 2. Before-after mean comparisons at the treatment site (GCB) and control site (FSB), were conducted with paired $t$-tests or for non-normal data the related-samples Wilcoxon signed ranks test (Freund and Wilson 1993). Variance in the before-after species assemblages for each treatment unit associated with predictor variables, based on species diversity, habitat structure, and functional group composition, was examined with distance-based linear models (Anderson et al. 2008). An Information Criterion (AIC; Akaike 1973) using the Best model selection procedure was used for estimating the optimal combination of predictor variables. Species abundance in the resemblance matrix was square-root transformed to lessen impact of dominant species. The data were examined for multicollinearity and highly correlated variables $\left(R^{2}>0.5\right)$ were removed from the model. Predictor variables based on species diversity and habitat structure (Shannon-Weiner index, tree density, tree basal area, and shrub-sapling density) were normalized for comparison. Variables based on sum percent cover for plant functional groups (percent cover of ferns and fern allies, annual-biennial forbs, perennial forbs, herbaceous legumes, $C_{3}$ grasses, $C_{4}$ grasses, sedges, woody seedlings, and woody vines) were squareroot transformed. Statistical significance for the degree of variance in species composition explained by predictor variables was determined with permutation tests $(n=999)$.

Question 3. I used forecast analysis (IBM SPSS 2019) to explore trends among vegetation parameters from the baseline estimation period (1989 to 1995) to model a forecast period (1996 to 2020). Data collected in 2006, 2013, and 2017, following the estimation period, were compared to projected trends to determine if observations fell below, stayed within, or exceeded the $95 \%$ forecast confidence intervals. For further testing of prediction accuracy, the estimation period was extended to 2006. Holt's linear trend exponential smoothing model (Holt 1957) was used for forecasting parameter trends because it is designed for linear trends without seasonality and it produced realistic model outcomes.

\section{Results}

\section{Gamma diversity and floristic quality}

Total species recorded in vegetation samples at GCB, the fire-treatment unit, began and ended with 94 taxa, peaking in the period from 1994 to 2006 at 121 species. At FSB, the fire-free control unit (sampled at $53 \%$ the intensity at GCB), the baseline total species was 74 and gradually declined to 59. Six different species ranked as most important at GCB during the study, and 11 species overall ranked among the five most important for any given year, accounting for $50 \%$ to $57 \%$ of the total IV among all species during each sample period (Table 1). At FSB, Danthonia spicata was the dominant species throughout the study. The mean coefficient of conservatism did not differ or vary, remaining around 4.5 at both study units throughout the study.

\section{Question 1: tests of parallelism}

The profile of trends between the GCB and FSB units were nonparallel with significant time $\times$ treatment interactions found for each overstory $(P<0.001)$ and ground layer $(P<0.005)$ parameter (Figs. 2 and 3$)$. Contrast differences for overstory parameters (planned post-hoc tests) indicated a lag-time fire effect for tree density and basal area following the first few burns (Fig. 2A, B) and few significant contrast differences 
Table 1 Lists of species that were among the five most dominant at Gibbons Creek Barrens, Pope County, Illinois, USA, based on percent importance value (\% IV = sum of relative cover and relative frequency) during each of nine years of vegetation monitoring (from 1989 to 2017) in the fire treatment unit. Percent IV shown in bold are values ranking among the top five for a given year. Species shown in bold were the most dominant during at least one year

\begin{tabular}{|c|c|c|c|c|c|c|c|c|c|c|}
\hline \multirow[b]{2}{*}{ Species } & \multicolumn{9}{|c|}{ Yearly importance value (\%) } & \multirow[b]{2}{*}{ Years in top five IV $(n)$} \\
\hline & 1989 & 1990 & 1991 & 1993 & 1994 & 1995 & 2006 & 2013 & 2017 & \\
\hline Acalypha gracilens Gray & 2.31 & 2.53 & 0.97 & 0.74 & 4.08 & 2.14 & 2.97 & 2.03 & 1.27 & 1 \\
\hline Amphicarpaea bracteata & 1.12 & 1.52 & 2.26 & 2.86 & 3.86 & 3.09 & 3.39 & 0.39 & 0.78 & 1 \\
\hline Carex albicans & 7.52 & 9.49 & 9.17 & 8.68 & 9.22 & 9.23 & 8.11 & 12.57 & 7.91 & 9 \\
\hline Danthonia spicata & 6.77 & 4.08 & 7.24 & 10.71 & 5.31 & 7.94 & 5.24 & 9.61 & 6.72 & 8 \\
\hline Dichanthelium laxiflorum & 4.08 & 5.12 & 11.96 & 13.35 & 9.72 & 10.79 & 6.62 & 5.56 & 7.08 & 8 \\
\hline Dichanthelium linearifolium & 2.07 & 2.28 & 3.31 & 3.23 & 2.30 & 2.50 & 1.79 & 6.51 & 2.51 & 1 \\
\hline Helianthus divaricatus & 8.92 & 8.12 & 8.42 & 8.01 & 8.95 & 10.11 & 14.03 & 10.90 & 5.85 & 8 \\
\hline Parthenocissus quinquefolia & 9.74 & 4.08 & 3.70 & 3.94 & 3.24 & 2.42 & 2.70 & 1.95 & 2.73 & 1 \\
\hline Potentilla simplex & 1.41 & 1.25 & 1.86 & 0.80 & 0.70 & 0.78 & 1.89 & 1.14 & 8.64 & 1 \\
\hline Schizachyrium scoparium & 11.26 & 6.11 & 4.85 & 5.03 & 4.08 & 3.05 & 4.00 & 5.38 & 6.07 & 6 \\
\hline Triodanis perfoliata L. Nieuwl. & 0.26 & 11.05 & 0.00 & 0.00 & 2.63 & 1.76 & 1.52 & 0.84 & 0.04 & 1 \\
\hline Sum of importance values (\%) & 55.47 & 55.63 & 53.75 & 57.36 & 54.09 & 53.80 & 52.26 & 56.89 & 49.59 & \\
\hline
\end{tabular}

for woody understory between treatment and control sites (Fig. 2C). In general, tree density declined with fire treatment, slowly at first and more progressively following the third and fourth burns. With fire absence, tree density increased slightly until a decline in the final sample. Basal area remained unchanged with fire treatment until after four burns, when there was a decline; with fire absence, basal area steadily increased until the final sample, when there was a decline. Shrub-sapling density showed increases and decreases at both GCB and FSB, with a pronounced increase at $\mathrm{GCB}$ in samples following the last fire treatment. Corresponding to this increase and despite continuing declines in tree density, total overstory cover increased from 2013 to 2017 at GCB during the post-fire period by a total of $26 \%$ (from $62.3 \%$ to $78.6 \%$ ), and at FSB by a total of $16 \%$ (from $70.6 \%$ to 81.6\%).

Ground-layer species density, richness, and diversity increased following burns at GCB and declined gradually during post-fire intervals; trends at FSB were characterized by gradual decline (Fig. 3A through E). Dominance declined with fire treatments until 2006, when subsequently it increased; dominance increased gradually without fire treatment. Percent cover in the groundlayer vegetation had been dynamic at GCB but declined overall; percent cover declined steadily at FSB except for year two of monitoring, when there was a mass flowering of the dominant grass, D. spicata. Contrast differences among ground-layer parameters were greatest during early and midterm periods (Fig. 3A though E). Percent ground cover over the term of the study was inversely correlated with shrub-sapling density at GCB $\left(\mathrm{R}^{2}=0.498, n=9, P=0.034\right)$ but not at FSB.

\section{Question 2: before-after paired comparisons Overstory}

Tree density from the 1989 baseline to 2017 declined at GCB and FSB (Table 2) and both differences exceeded random expectations (Fig. 2A). There was a decline in basal area at GCB and a slight increase at FSB (Table 2, Fig. 2B). With fire treatment, stem reduction was primarily among the 5 to $20 \mathrm{~cm}$ DBH size classes; with fire absence, minor stem losses in the smallest size classes were compensated by increases in next larger class (Fig 4). Canopy composition at GCB remained strongly dominated by Q. stellata, despite a $48 \%$ reduction in stem density, followed by Ulmus alata, Carya species, and Fraxinus americana L. With fire absence at FSB, there has been a reversal in dominance following gains among $U$. alata ( $44 \%$ increase in stem density) and declines among Q. stellata (46\% decline in stem density; Additional file 1).

Shrub-sapling density increased at GCB and FSB; however, only the increase at GCB exceeded the null expectation (Table 2; Fig. 2C). Species increasing the greatest at GCB (>300 stems ha ${ }^{-1}$ ) were Rhus copallinum L., Q. stellata, Symphoricarpos orbiculatus Moench, Amelanchier arborea (Michx. f.) Fernald, and Carya texana (Additional file 2).

\section{Ground layer}

Comparing baseline 1989 to 2017 values at GCB, there were increases in species density, richness, and diversity; these values declined or remained nearly the same at FSB 


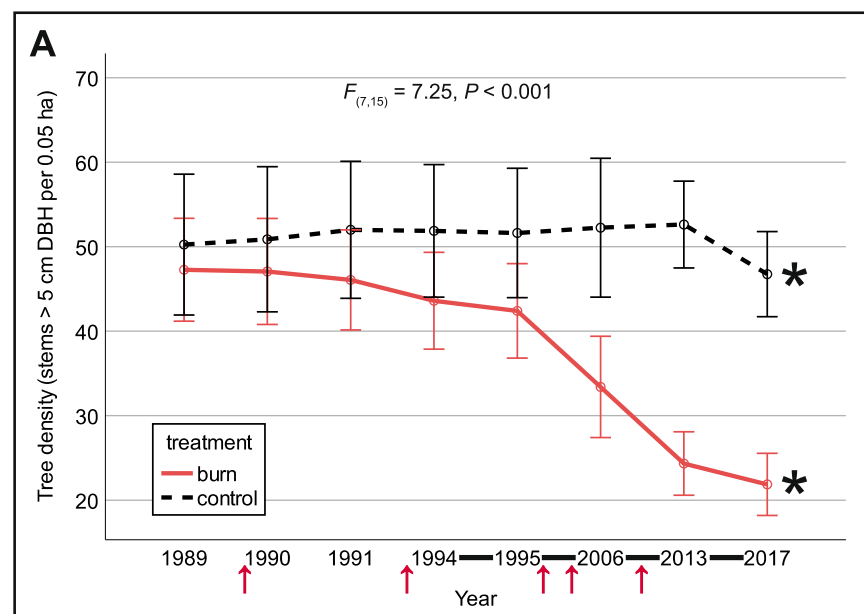

B
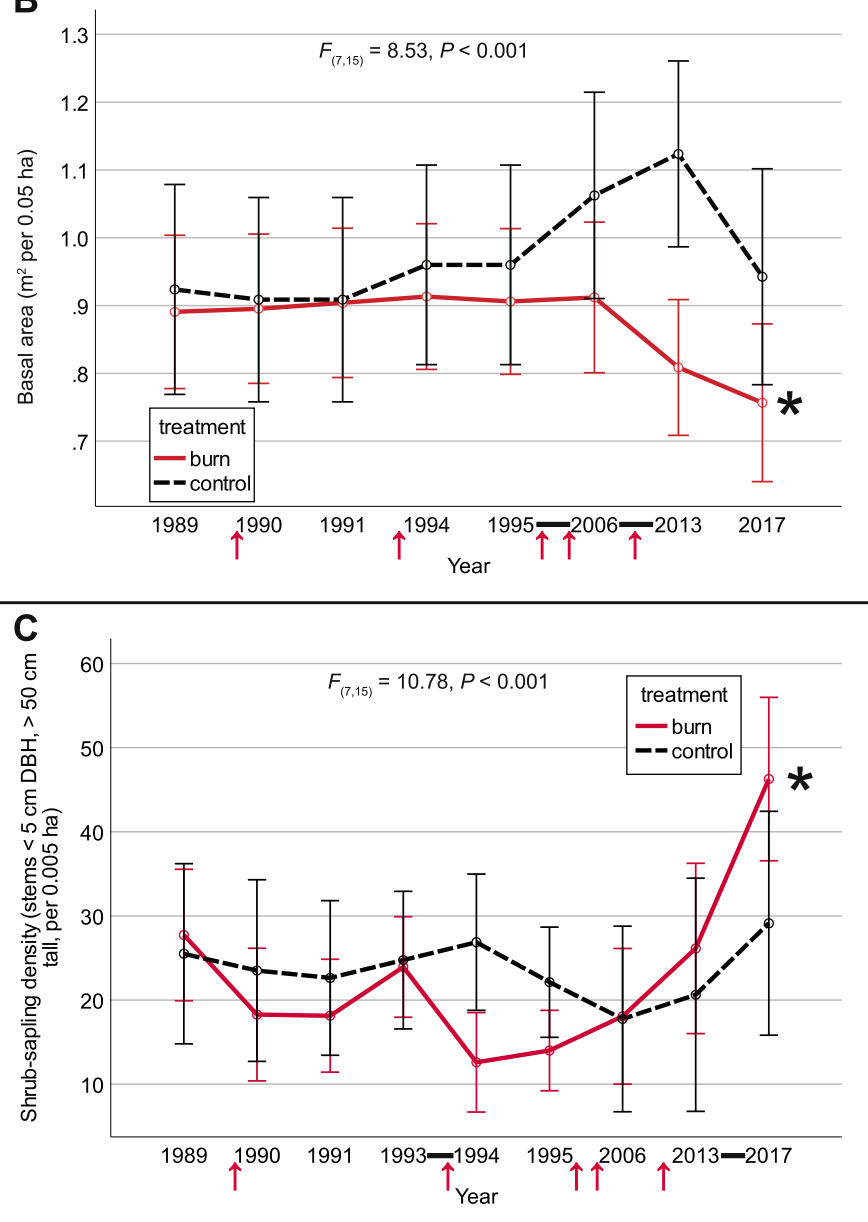

Fig. 2 Overstory trends comparing outcomes from 1989 to 2017 at the fire-treatment (GCB) and fire-free control units (FSB) of Gibbons Creek Natural Area, Pope County, Illinois, USA. (A) Trends for tree density (woody stems $\geq 5 \mathrm{~cm} \mathrm{DBH}$ per $0.05 \mathrm{ha}$ ); (B) trends for tree basal area ( $\mathrm{m}^{2}$ per 0.05 ha); (C) trends for shrub-sapling density (woody stems $<5 \mathrm{~cm} \mathrm{DBH}, \geq 50 \mathrm{~cm}$ in height per $0.005 \mathrm{ha}$ ). Shown are the F-test results from mixed model repeat measures ANOVA using Pillai's trace MANOVA statistic, the test for parallelism in profile analysis. Significant post hoc test results examining between-year contrast difference between GCB and FSB using the Bonferroni adjustment for trees ( 7 contrasts, $a=0.007$ ) and shrubsapling (8 contrasts, $a=0.006$ ) strata are indicated with a line between years. Error bars are $95 \%$ confidence intervals. Significant paired comparisons between baseline and final sample period for both GCB and FSB are indicated by asterisks (*) near the right margin. Red arrows indicate times of fire treatments at GCB 


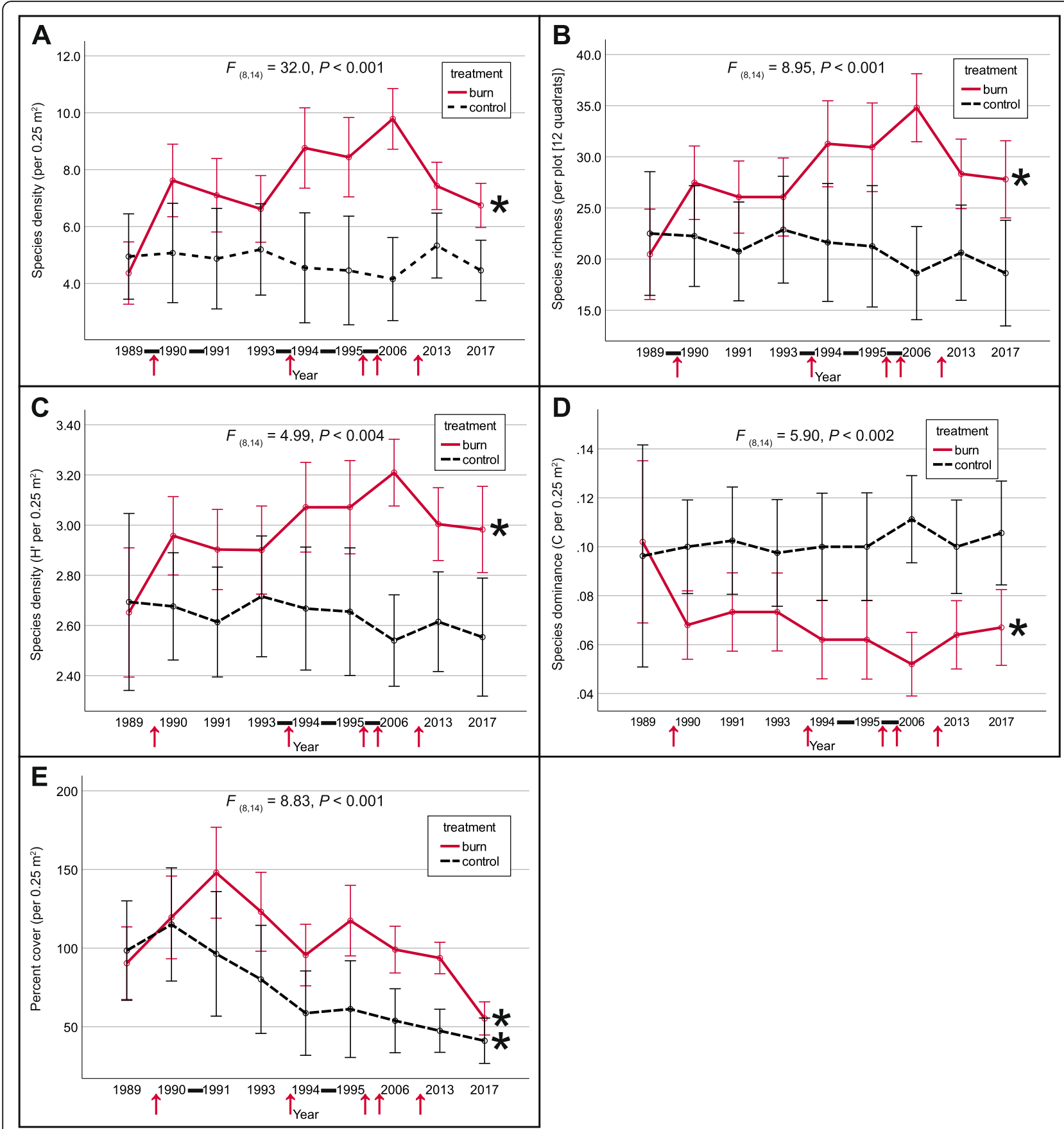

Fig. 3 Trends for ground-layer parameters comparing outcomes from 1989 to 2017 at the fire-treatment (GCB) and fire-free control (FSB) units of Gibbons Creek Natural Area, Pope County, Illinois, USA. (A) Trends for species density (species number per $0.25 \mathrm{~m}^{2}$ ); (B) trends for species richness (sum from $120.25 \mathrm{~m}^{2}$ quadrats per 0.05 ha plot); (C) trends for species diversity (Shannon-Weiner index [H'] per $0.25 \mathrm{~m}^{2}$ ); (D) trends for species dominance (Simpson's index [C] per $0.25 \mathrm{~m}^{2}$ ); (E) trends for percent cover (per $0.25 \mathrm{~m}^{2}$ ). Shown are the F-test results from mixed model repeat measures ANOVA using Pillai's trace MANOVA statistic, the test for parallelism in profile analysis. Significant post hoc test results examining between year contrast difference between GCB and FSB using the Bonferroni adjustment ( 8 contrasts, $a=0.006$ ) are indicated with a line between years. Error bars are 95\% confidence intervals. Significant paired comparisons between baseline and final sample period for both GCB and FSB are indicated by asterisks $\left(^{*}\right)$ near the right margin. Red arrows indicate times of fire treatments at GCB 
Table 2 Paired comparison tests for burn and control treatments comparing 1989 baseline data to 2017 sample data for eight vegetation parameters at Gibbons Creek Barrens Natural Area, Pope County, Illinois, USA. se = standard error. If "mean \pm " is shown, data were analyzed with paired t-tests; if "mdn" (median) is shown, data were analyzed with related samples Wilcoxon signed-rank tests because either 1989 or 2017 data were not normally distributed. GCB = Gibbons Creek Barrens, FSB = Forest Service Barrens, Change $(\%)=$ difference between 1989 and 2017, df = degrees of freedom, Test stat = test statistic, $P=$ probability, NA = not applicable. $P$ values shown in bold are significant $(<0.05)$

\begin{tabular}{|c|c|c|c|c|c|c|c|c|c|c|}
\hline \multirow[b]{2}{*}{ Parameter } & \multicolumn{10}{|c|}{ Treatment: Burn (GCB) } \\
\hline & \multicolumn{2}{|c|}{1989 (mean \pm se) } & \multicolumn{4}{|c|}{2017 (mean \pm se) } & \multirow[t]{2}{*}{ Change (\%) } & \multirow[t]{2}{*}{ Test stat } & \multirow[t]{2}{*}{ df } & \multirow[t]{2}{*}{$P$} \\
\hline Overstory & & & & & & & & & & \\
\hline Tree density (stems per 0.05 ha) & 47.27 & \pm & 12.50 & 21.87 & \pm & 7.18 & -53.74 & 8.40 & 14 & $<0.001$ \\
\hline Tree basal area ( $\mathrm{m}^{2}$ per $\left.0.05 \mathrm{ha}\right)$ & 0.89 & \pm & 0.06 & 0.76 & \pm & 0.06 & -15.04 & 4.60 & 14 & $<0.001$ \\
\hline Shrub and sapling density (stems per 0.005 ha) & 27.73 & \pm & 3.70 & 46.27 & \pm & 5.35 & 66.83 & -5.68 & 14 & $<0.001$ \\
\hline \multicolumn{11}{|l|}{ Ground layer } \\
\hline Species density (species per 0.25 m) & 4.37 & \pm & 0.60 & 6.75 & \pm & 0.42 & 54.45 & -6.66 & 14 & $<0.001$ \\
\hline Species richness (total species per plot [12 quadrats]) & 21.00 & mdn & NA & 26.00 & mdn & NA & 23.81 & 113.00 & & 0.003 \\
\hline Species diversity $\left(\mathrm{H}^{\prime}\right.$ per $\left.0.25 \mathrm{~m}^{2}\right)$ & 2.76 & mdn & NA & 2.90 & mdn & NA & 5.07 & 108.00 & & 0.006 \\
\hline Dominance (C per $0.25 \mathrm{~m}^{2}$ ) & 0.08 & mdn & NA & 0.07 & mdn & NA & -13.75 & 8.50 & & 0.003 \\
\hline Cover $(\%)$ & 90.42 & \pm & 13.06 & 55.31 & \pm & 4.93 & -38.83 & 2.85 & 14 & 0.013 \\
\hline \multirow[t]{2}{*}{ Parameter } & \multicolumn{6}{|c|}{ Treatment: Control (FSB) } & & & & \\
\hline & \multicolumn{2}{|c|}{$1989($ mean \pm se) } & \multicolumn{4}{|c|}{2017 (mean \pm se) } & Change (\%) & Test stat & df & $P$ \\
\hline \multicolumn{11}{|l|}{ Overstory } \\
\hline Tree density (stems per 0.05 ha) & 50.25 & \pm & 3.02 & 46.75 & \pm & 2.17 & -6.97 & 3.44 & 7 & 0.011 \\
\hline Tree basal area ( $\mathrm{m}^{2}$ per $\left.0.05 \mathrm{ha}\right)$ & 0.92 & \pm & 0.05 & 0.94 & \pm & 0.08 & 2.03 & -0.48 & 7 & 0.644 \\
\hline Shrub and sapling density (stems per 0.005 ha) & 25.50 & \pm & 5.31 & 29.13 & \pm & 3.92 & 14.22 & -1.09 & 7 & 0.311 \\
\hline \multicolumn{11}{|l|}{ Ground layer } \\
\hline Species density (species per 0.25 m) & 4.38 & mdn & NA & 4.42 & mdn & NA & 1.03 & 8.50 & & 0.352 \\
\hline Species richness (total species per plot [12 quadrats]) & 22.50 & \pm & 2.76 & 18.63 & \pm & 2.03 & -17.22 & 1.53 & 7 & 0.169 \\
\hline Species diversity ( $\mathrm{H}^{\prime}$ per $0.25 \mathrm{~m}^{2}$ ) & 2.69 & \pm & 0.13 & 2.55 & \pm & 0.13 & -5.20 & 1.38 & 7 & 0.210 \\
\hline Dominance (C per $\left.0.25 \mathrm{~m}^{2}\right)$ & 0.10 & \pm & 0.01 & 0.11 & \pm & 0.01 & 9.74 & -0.91 & 7 & 0.392 \\
\hline Cover (\%) & 98.42 & \pm & 7.26 & 41.12 & \pm & 7.27 & -58.22 & 9.30 & 7 & $<0.001$ \\
\hline
\end{tabular}

(Table 2, Fig. 3A to C). Dominance declined at GCB and increased slightly at FSB. Percent cover declined at both GCB and FSB (Table 2, Fig. 3D, E). Before-after trends among vegetation parameters are summarized in Table 3.

The combination of predictor variables most associated with differences in ground-layer species composition and abundance between treatment groups and before-after sample periods are, in descending rank order of explained variance from marginal tests in distance-based linear modeling: $C_{4}$ grass cover, $C_{3}$ grass cover, ground-layer species diversity, woody vine cover, perennial forb cover, perennial sedge cover, tree basal area, annual-biennial forb cover, tree density, and cover of woody seedlings. This combination of predictor variables was estimated to explain $52 \%$ of the variance in species composition.

$C_{4}$ grasses and $C_{3}$ grasses and sedges have declined in general at GCB and FSB (Fig. 5). Total ground-layer percent cover during the study was highly correlated to graminoid cover (sum of grass and sedge cover) at both the fire treatment and control units, $\mathrm{R}^{2}=0.79$ and 0.99 $(n=9)$, respectively; consequently, much of the loss in overall ground-layer percent cover is attributable to declining graminoid cover. Gains in species richness with fire treatments primarily were among perennial forbs and $C_{3}$ grasses, while losses were among woody species; with fire absence, the greatest losses were among perennial forbs and seedlings of woody species (Fig. 5).

Sørensen's coefficient of similarity (Cs) for species recorded at the baseline and final sample was Cs $=0.72$ for both units. Most species recorded in either or both 1989 and $2017(n=114)$ declined in percent cover, but more declined in the fire-free control unit $(72.3 \%)$ than in the fire treatment unit (59.6\%). With fire treatment, $61 \%$ of species increased, or remained the same frequency $(n=5)$, compared to nearly $45 \%$ without fire. At GCB, $35 \%$ of 


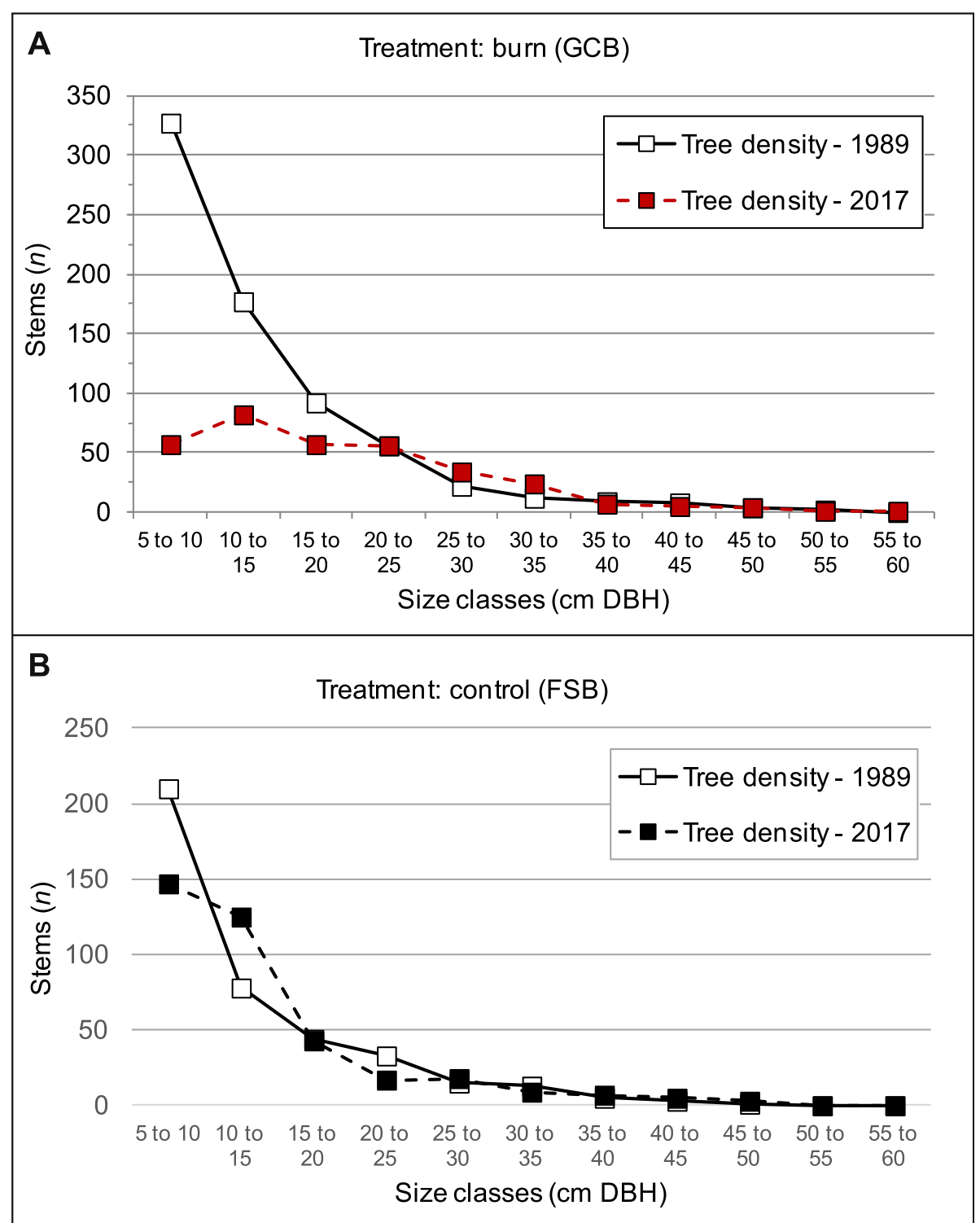

Fig. 4 Distribution of tree size classes comparing 1989 baseline sample to 2017 final sample for (A) fire-treatment unit (GCB) and (B) fire-free control unit (FSB) of the Gibbons Creek Barrens Natural Area, Pope County, Illinois, USA. Data is from 150.05 ha plots at GCB and eight 0.05 ha plots at FSB. Fire treatments at GCB occurred on 27 November 1989, 16 March 1994, 3 April 1997, 2 March 2006, and 19 March 2010. GCB = Gibbons Creek Barrens, FSB = Forest Service Barrens, DBH = diameter at breast height

species increased in both frequency and cover compared to $25.3 \%$ at FSB; $40 \%$ of species decreased in both frequency and cover at GCB compared to $55.4 \%$ at FSB (Additional file 3). Based on before-after differences in percent cover, the greatest changes with fire treatment (GCB) included the increasing species $(>0.5 \%$ cover $)$ Potentilla simplex, Cunila origanoides (L.) Britton, Clitoria mariana L., Dichanthelium laxiflorum, Parthenium integrifolium L., Gillenia stipulata (Muhl. ex Willd.) Baill., and Quercus stellata; species decreasing most in cover $(>1.0 \%)$ with fire treatment were Schizachyrium scoparium,
Parthenocissus quinquefolia (L.) Planch., Helianthus divaricatus, Danthonia spicata, Carex albicans, Dichanthelium boscii (Poir.) Gould \& C.A. Clark, Andropogon gerardii Vittman, and Sorghastrum nutans (L.) Nash. With fire absence (FSB), species increasing greatest in percent cover $(>0.1 \%)$ were Potentilla simplex, Lespedeza repens (L.) W.P.C. Barton, Quercus stellata, and Manfreda virginica (L.) Salisb. ex Rose; species decreasing most in cover (>3.0\%) were Danthonia spicata, Dichanthelium laxiflorum, Schizachyrium scoparium, Carex albicans, and Helianthus divaricatus (Additional file 3). 
Table 3 Summary of before-after $(1989,2017)$ trends among vegetation parameters at the Gibbons Creek Barrens Natural Area, Pope County, Illinois, USA. Significant changes $(P<0.05)$ are highlighted with bold capital ex $(\mathbf{X})$; non-significant trends indicated with lowercase ex (x). GCB = Gibbons Creek Barrens, FSB $=$ Forest Service Barrens

\begin{tabular}{|c|c|c|c|c|}
\hline \multirow[b]{2}{*}{ Parameter } & \multicolumn{2}{|c|}{ Treatment: Burn (GCB) } & \multicolumn{2}{|c|}{ Treatment: Control (FSB) } \\
\hline & Decrease & Increase & Decrease & Increase \\
\hline \multicolumn{5}{|l|}{ Overstory } \\
\hline Tree density & $\mathrm{x}$ & & $x$ & \\
\hline Tree basal area & $x$ & & & $x$ \\
\hline Shrub-sapling density & & $\mathrm{x}$ & & $x$ \\
\hline \multicolumn{5}{|l|}{ Ground layer } \\
\hline Species density & & $x$ & & $x$ \\
\hline Species richness & & $\mathrm{x}$ & $x$ & \\
\hline Species diversity & & $x$ & $x$ & \\
\hline Species dominance & $x$ & & & $x$ \\
\hline Percent cover & $x$ & & $x$ & \\
\hline
\end{tabular}

\section{Question 3: forecast analyses}

Observations at GCB recorded in 2006, 2013, and 2017, for many vegetation parameters following the 1989 to 1995 estimation period, fall outside the projected 95\% confidence intervals. In contrast, observations at FSB generally were more predictable based on initial estimation period, with some notable exceptions (Table 4).

\section{Overstory}

Observed tree density at GCB fell below expectation while basal area remained within expectation; in contrast, tree density at FSB stayed within expectations while observed basal area fell far below (Fig. 6A through D). Using the period from 1989 to 2006 as the estimation period did not improve predictions; basal area at GCB fell below expectations (Table 4). Observations for shrub-sapling density at GCB far exceeded prediction for both estimation periods (Fig. 6E, Table 4); at FSB, shrub-sapling density was as predicted with the 1989 to 1995 estimation model, although nearly exceeding limits of the $95 \%$ confidence interval (Fig. 6F), and exceeded expectations when using the 1989 to 2006 estimation period (Table 4).

\section{Ground layer}

Measures of species density, richness, and diversity generally fell below expectation of increase at GCB while they exceeded (species density) or remained within expectations of decline at FSB (Fig. 7A through F). Species dominance did not decline as much as expected at GCB and stayed within expectations at FSB of gradual increase (Fig. 7G, H). Percent cover fell at both GCB and FSB, but only at GCB was the decline greater than expected (Fig. 7I, J), particularly in later years during periods of rapid increase in subcanopy cover.
Characteristic $\mathrm{C}_{4}$ grasses of the oak barrens habitat were in parallel decline between GCB and FSB during the estimation period. Although these trends generally continued, the forecast prediction that $\mathrm{C}_{4}$ grasses would diminish until extirpated from both sites has not occurred (Fig. 8A, B). Although both $\mathrm{C}_{3}$ grass and sedge cover declined at both units, with fire treatment the declines contrasted with expectations of increase, and with fire absence the declines were less than expected (Fig. $8 \mathrm{C}$ through F).

In terms of forecasting collective species' responses, during the 1989 to 1995 estimation period, 46 species increased in both frequency and percent cover, which was the most common species response associated with fire treatment (Additional file 3); however, of these, only $30 \%$ continued those trends while most increaser species during the estimation period ultimately declined in frequency, or cover, or both. Of the eight species decreasing in frequency during the estimation period, only one reversed that trend (Rubus pensylvanicus Poir.), while the remainder continued to decline in cover, including the $\mathrm{C}_{4}$ grasses Andropogon gerardii, Schizachyrium scoparium, and Sorghastrum nutans (the latter increased in frequency but declined in cover).

\section{Discussion}

Management objectives in oak-savanna-like habitats may fundamentally differ from more closed oak woodland and forest ecosystems. In woodlands and forests, due to the well documented oak decline and mesophication in these ecosystems in the eastern United States (Abrams 2005; Nowacki and Abrams 2008), there may be an emphasis on the promotion of oak regeneration with applications of prescribed fire (Brose et al. 2014; Iverson et al. 2017). However, the goals with fire management in oak savanna oftentimes is to limit woody encroachment (thicketization), more or less regardless of species, to promote ground-layer flora. Oak regeneration may not be limited in openings and can become a problem if it contributes to further woody encroachment and competition with the herb layer for available light. Consequently, expectations from an effective fire management program in oak savanna following extended fire absence, in keeping with the restoration hypothesis, would include reductions in overstory and understory stand density and increases in ground-layer species diversity and percent cover of species representative of the habitat.

In this study, the consistent differences in trend profiles for measured vegetation parameters between GCB, the fire-treatment unit, and FSB, the fire-free control unit, and the greater before-after differences at GCB are very likely the result of five burns between 1989 and 2017. By these measures, fire treatments have been successful. However, predictions based on early trends 


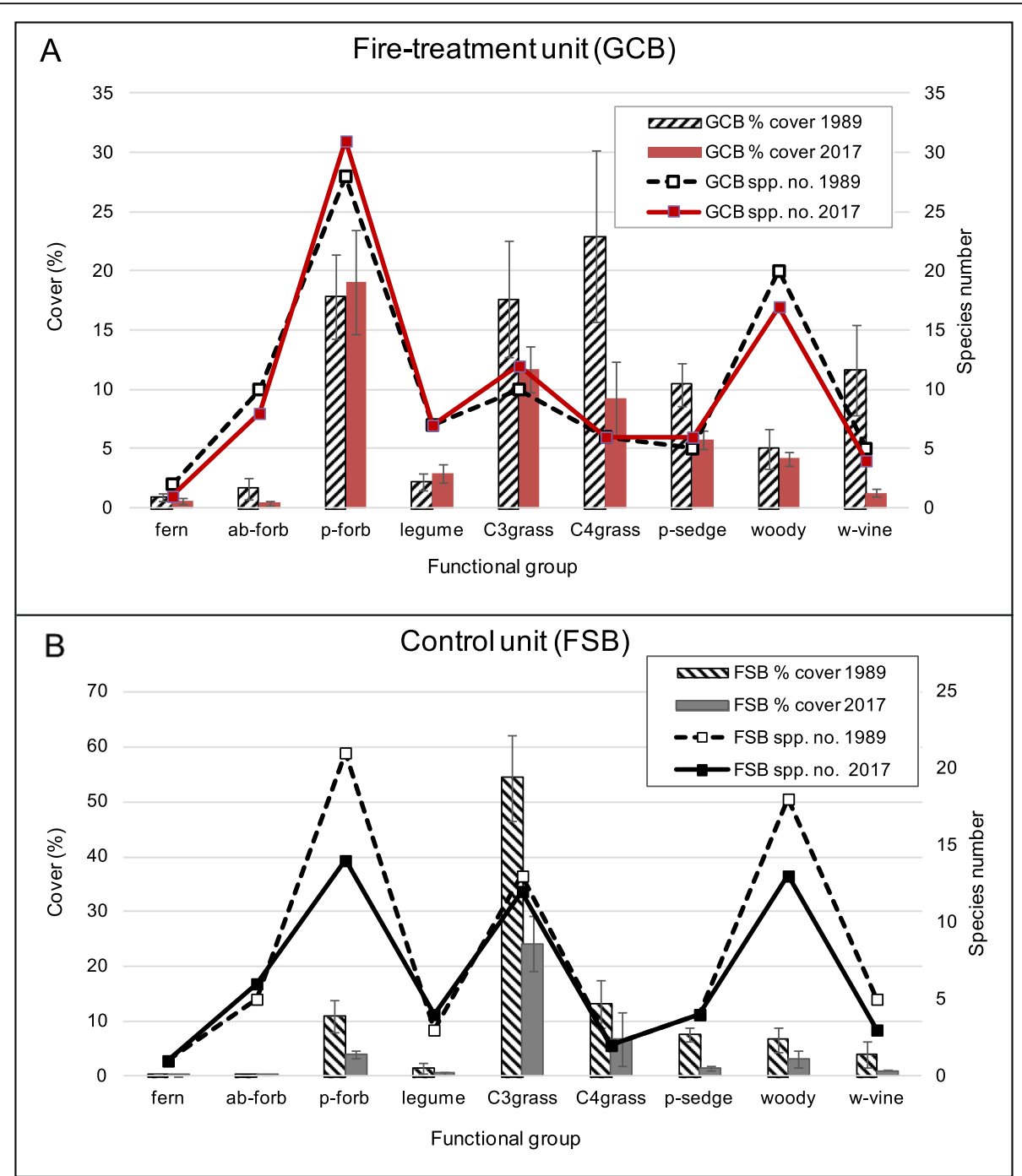

Fig. 5 Before-after (1989 and 2017) differences in sum percent cover and species richness for plant functional groups at (A) fire treatment unit (GCB) and (B) fire-free control unit (FSB) of the Gibbons Creek Barrens Natural Area, Pope County, Illinois, USA. Ab = annual and biennial, $p=$ perennial, $\mathbf{w}=$ woody, spp. no. = species number, GCB = Gibbons Creek Barrens, FSB $=$ Forest Service Barrens

were unreliable for many parameters, particularly at $\mathrm{GCB}$, where structural components of the overstory declined more than expected, woody understory increased more than predicted, and ground-layer species richness and diversity, although increased, did not keep pace with the degree of expected increases.

\section{Overstory}

Fire as a management tool in oak savanna and woodland communities is often prescribed as a treatment for woody encroachment with varying results, depending on fire frequency, fire intensity, years since last burn, and stem size (Tester 1989; Peterson and Reich 2001; Dey and Hartman 2005). In general, infrequent, particularly low-intensity, fire may have negligible results on overstory stand structure and can even promote sapling density through sprouting (Peterson and Reich 2001; Haney et al. 2008). Frequent fires can be effective at reducing small-diameter trees with differential effects on tree species favoring select oak species (Peterson and Reich 2001; Brose et al. 2006; Haney et al. 2008; Knapp et al. 2016) as well as controlling woody understory species (Bowles et al. 2007; Peterson et al. 2007). However, contrasting results have been found in relatively closed oak woodland habitats in Oklahoma, USA, where canopy cover, basal area, and stem density showed no relationship to fire frequency (Burton et al. 2011).

A particularly relevant question for restorationists is whether treatment with fire alone can achieve management goals following extended fire-free intervals and resultant thicketization. Mechanical thinning combined with burning can be effective at achieving stem 
Table 4 Outcomes of forecast analyses comparing observations at fire-treatment and fire-free control units of Gibbons Creek Barrens Natural Area, Pope County, Illinois, USA, from 2006, 2013, and 2017, to trends predicted within 95\% confidence intervals (Cl) from a 7-year early-estimation period (1989 to 1995). Also shown are outcomes from a separate analysis using a wider estimation period (1989 to 2006). $x$ = based on forecast period from 1989 to 1995; $y=$ based on forecast period from 1989 to 2006. GCB = Gibbons Creek Barrens, FSB = Forest Service Barrens

\begin{tabular}{|c|c|c|c|c|c|c|}
\hline \multirow[b]{2}{*}{ Parameter } & \multicolumn{3}{|c|}{ Treatment: Burn (GCB) } & \multicolumn{3}{|c|}{ Treatment: Control (FSB) } \\
\hline & Below $\mathrm{Cl}$ & Within $\mathrm{Cl}$ & $\overline{\text { Above } \mathrm{Cl}}$ & Below $\mathrm{Cl}$ & Within $\mathrm{Cl}$ & $\overline{\text { Above } \mathrm{Cl}}$ \\
\hline \multicolumn{7}{|l|}{ Overstory } \\
\hline Tree density & $x, y$ & & & & $x, y$ & \\
\hline Tree basal area & y & $x$ & & $x, y$ & & \\
\hline Shrub-sapling density & & & $x, y$ & & $x$ & y \\
\hline \multicolumn{7}{|l|}{ Ground Layer } \\
\hline Species density & $x, y$ & & & & & $x, y$ \\
\hline Species richness & $x, y$ & & & & $x$ & y \\
\hline Species diversity & $x, y$ & & & & $x$ & y \\
\hline Species dominance & & & $x, y$ & y & $x$ & \\
\hline Percent cover & $x$ & y & & & y & $x$ \\
\hline
\end{tabular}

reduction as well as encourage oak regeneration (Iverson et al. 2017), but can be costly, labor intensive, and sometimes ephemeral (Bassett et al. 2020). Furthermore, at least in thicketized grasslands, mechanical treatments can lead to habitat damage when heavy equipment is utilized (Taft et al. 2019). Although initial outcomes regarding canopy stem reduction in this study following two burns were inconclusive (Taft 2003), following a total of five burns during the period from 1989 to 2013 (mean fire-return interval of $4.8 \mathrm{yr}$ ), tree density at GCB declined $48 \%$, from 47 stems per 0.05 ha plot to 24 stems per 0.05 ha plot, a level recognized as a management goal from baseline data that suggested greater stand densities were associated with declining groundlayer diversity (Taft and Solecki 2002).

In the final sample, there also was a sharp drop in stem density and basal area at the FSB control site, possibly attributable to a disease specific to the white oak group including Quercus stellata, termed rapid white oak mortality, recently observed for the region (Reed et al. 2017; Wood et al. 2018). The severity of the disease may have been exacerbated by severe drought in 2012 (Rippey 2015). Consequently, fire, drought, and disease may have interacted at GCB, contributing to the observed declines following the estimation period. While at first the decline at GCB was among small-diameter trees, more recent mortality among a few larger trees contributed to the observed decline in basal area. Interactions between fire and drought contributing to mortality have been implicated for white oak seedlings in forests in the Shawnee National Forest, Illinois (Refsland and Fraterrigo 2018) and conifer forests throughout the western United States (van Mantgem et al. 2013).
Less successful has been control of the woody understory with fire treatment whereby density of shrubs and saplings increased 67\% from the 1989 baseline, with much of the increase occurring during the six-year post-fire interval from 2011 to 2017. The response was species specific with some limited control of Ulmus. alata, the former dominant species, but great increases among clonal shrubs (Symphoricarpos orbiculatus, Rhus copallinum) and tree resprouts (Quercus stellata, Carya texana). A return to nearly baseline understory stem density occurred after only two years following the last burn; rapid increase in woody understory also has been reported following fire in other oak woodlands and savannas (Haney et al. 2008; Burton et al. 2011). Rhus copallinum was the only shrub to increase in a long-term fire effects study in central Tennessee (DeSelm et al. 1991). With greater control of overstory stand density, the $26 \%$ increase in canopy coverage observed during the final two samples can be attributed to this increase in the subcanopy stratum, reversing, to an extent, progress in opening the stand for promotion of light-dependent ground-layer species. Compared with spring burns, which were the majority of burns at GCB, frequent fall and winter burns were most effective at controlling another invasive clonal shrub, Rhus glabra L., in grasslands (Hajny et al. 2011). Further research is needed in oak savanna and woodland habitats to determine the optimal fire season for achieving greatest control of woody species, particularly clonal shrubs.

\section{Ground layer}

In this study, ground-layer species density, richness, and diversity were highly responsive to fire treatments, with 


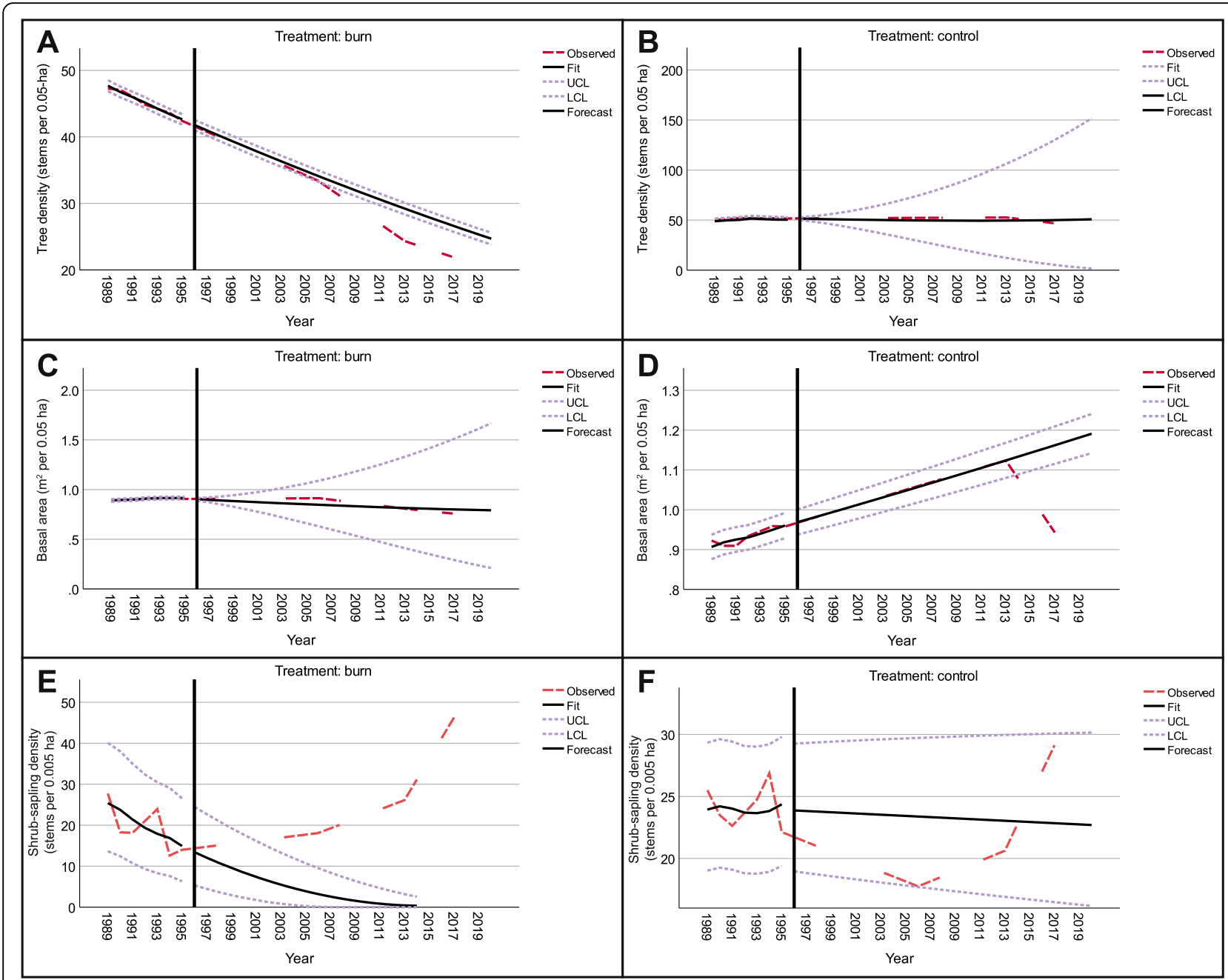

Fig. 6 Forecast analysis for parameters of woody strata at fire-treatment (GCB) and fire-free control (FSB) units of the Gibbons Creek Barrens Natural Area, Pope County, Illinois, USA. Shown are observed results from estimation (1989 to 1995) and forecast periods (1996 to 2017), left and right of vertical line, respectively, with the fit from forecast analysis using Holt's linear trend exponential smoothing model (Holt 1957) and the upper 95\% confidence limit (UCL) and lower 95\% confidence limit (LCL). (A) Estimation and forecast trends for tree density (woody stems $\geq 5 \mathrm{~cm}$ DBH per $0.05 \mathrm{ha}$ ) at GCB; (B) estimation and forecast trends for tree density at FSB; (C) estimation and forecast trends for tree basal area $\left(\mathrm{m}^{2}\right.$ per $\left.0.05 \mathrm{ha}\right)$ at $\mathrm{GCB} ;(\mathbf{D})$ estimation and forecast trends for tree basal area at FSB; (E) estimation and forecast trends for shrub-sapling density (woody stems $<5 \mathrm{~cm} \mathrm{DBH}, \geq 50 \mathrm{~cm}$ in height per $0.005 \mathrm{ha}$ ) at GCB; (F) estimation and forecast trends for shrub-sapling density at FSB. Fire treatments at GCB occurred on 27 November 1989, 16 March 1994, 3 April 1997, 2 March 2006, and 19 March 2010

notable increases following the first four burns, each followed by a gradual post-burn attrition, with species density nevertheless more than doubling from baseline levels to nearly 10 species per $0.25 \mathrm{~m}^{2}$ by 2006 . Fire had limited impact on ground-layer species diversity or composition in early stages of fire effects studies in Ohio mixed-oak forests (Hutchinson et al. 2005). More frequent burns over longer time spans have generally resulted in increased species diversity in oak savannas and woodlands (White 1983; Tester 1989; Bowles et al. 2007; Peterson et al. 2007). Again, somewhat contrasting results have been found in relatively closed oak woodland in Oklahoma, where species richness and diversity increased with fire frequency, although only the increase in diversity was significant and neither measure showed a relationship to time since last burn (Burton et al. 2011).

However, observations at GCB in 2013 following the fifth burn, in 2010, recorded a decline in these values that was counter to the antecedent pattern; these values uncharacteristically increased slightly at FSB during 2013. The differential response may be a consequence of drought-induced vulnerability during 2012, when leaf litter at GCB would have been reduced as a buffer against loss of soil moisture during an ensuing severe drought that started during 2011 


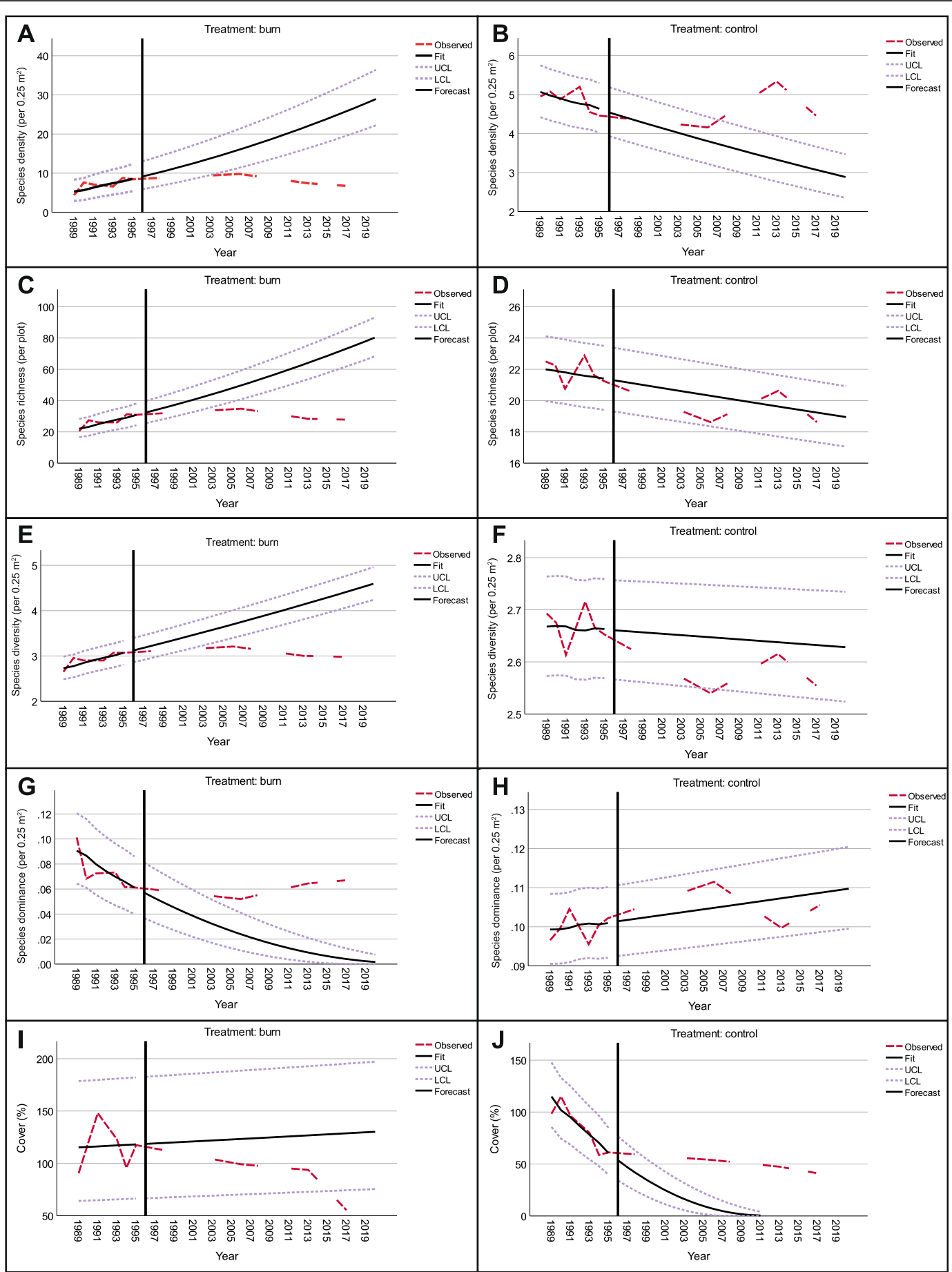

Fig. 7 Forecast analysis for parameters of the ground layer at fire-treatment (GCB) and fire-free control (FSB) units of the Gibbons Creek Barrens Natural Area, Pope County, Illinois, USA. Shown are observed results from estimation (1989 to 1995) and forecast periods (1996 to 2019 ), left and right of vertical line, respectively, with the fit from forecast analysis using Holt's linear trend exponential smoothing model (Holt 1957) and the upper 95\% confidence limit (UCL) and lower 95\% confidence limit (LCL). (A) Estimation and forecast trends for species density (per $\left.0.25 \mathrm{~m}^{2}\right)$ at GCB; (B) estimation and forecast trends for species density at FSB; (C) estimation and forecast trends for species richness (per plot $\left[120.25 \mathrm{~m}^{2}\right.$ quadrats]) at GCB; (D) estimation and forecast trends for species richness at FSB; (E) estimation and forecast trends for species diversity ( $H^{\prime}$ per $\left.0.25 \mathrm{~m}^{2}\right)$ at $\mathrm{GCB} ;(\mathbf{F})$ estimation and forecast trends for species diversity at FSB; (G) estimation and forecast trends for species dominance (C per $0.25 \mathrm{~m}^{2}$ ) at $\mathrm{GCB} ;(\mathbf{H})$ estimation and forecast trends for species dominance at FSB; (I) estimation and forecast trends for percent cover (per 0.25-m²) at GCB; (J) estimation and forecast trends for percent cover at FSB. Fire treatments at GCB occurred on 27 November 1989, 16 March 1994, 3 April 1997, 2 March 2006, and 19 March 2010 


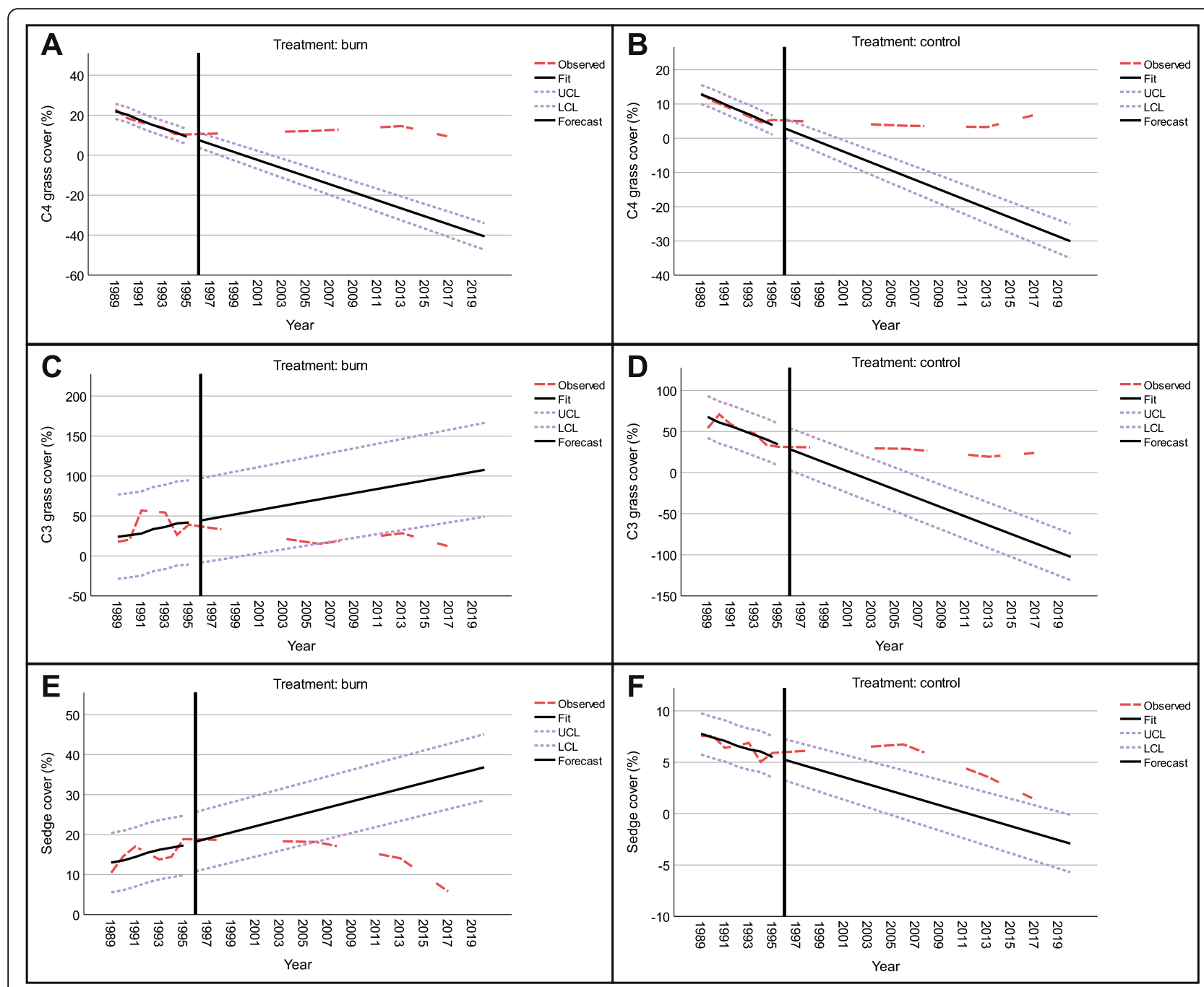

Fig. 8 Forecast analysis for graminoid species groups at fire-treatment (GCB) and fire-free control (FSB) units of the Gibbons Creek Barrens Natural Area, Pope County, Illinois, USA. Shown are observed results from estimation (1989 to 1995) and forecast periods (1996 to 2019), left and right of vertical line, respectively, with the fit from forecast analysis using Holt's linear trend exponential smoothing model (Holt 1957) and the upper 95\% confidence limit (UCL) and lower 95\% confidence limit (LCL). (A) Estimation and forecast trends for percent $\mathrm{C}_{4}$ grass cover (per $0.25 \mathrm{~m}^{2}$ ) at GCB; (B) estimation and forecast trends for percent $C_{4}$ grass cover at FSB; (C) estimation and forecast trends for percent $C_{3}$ grass cover (per $0.25 \mathrm{~m}^{2}$ ) at $\mathrm{GCB} ;(\mathbf{D})$ estimation and forecast trends for percent $C_{3}$ grass cover at FSB; (E) estimation and forecast trends for percent sedge cover (per $0.25 \mathrm{~m}^{2}$ ) at GCB; (F) estimation and forecast trends for percent sedge cover at FSB. Fire treatments at GCB occurred on 27 November 1989, 16 March 1994, 3 April 1997, 2 March 2006, and 19 March 2010

and continued through 2012 (Rippey 2015). The further decline in ground-layer cover at GCB in the final sample seven years after the last burn, particularly among graminoid species, corresponds to an increase in ground-layer species dominance and understory woody stem increase. Grass cover of $\mathrm{C}_{3}$ and especially $\mathrm{C}_{4}$ species was greatest in relatively frequently (biennial) burned open oak savannas and woodlands in Minnesota (Peterson et al. 2007). Late dormantseason burns can dampen $\mathrm{C}_{3}$ grass cover (Towne and Owensby 1984); however, that has not been found to be a factor in Minnesota oak savanna and woodland (Peterson et al. 2007). Increase in perennial forb cover could exert competition with graminoids, but the increase at GCB has been only slight. Species and functional group attrition corresponding with woody encroachment has been observed for mesic barrens in southern Illinois following 15 years of fire absence (Anderson and Schwegman 1991), and the phenomenon has been widely documented for grassland habitats, including prairie (Lett and Knapp 2003; Briggs et al. 2005; Milbauer and Leach 2007; Taft and Kron 2014). Abrupt and difficult to reverse transitions from mesic grassland dominated by $\mathrm{C}_{4}$ grasses to shrubland reported from the Great Plaines followed gradual decline in grass cover (Ratajczak et al. 2014). 
From data in the current study, it appears that optimal conditions were reached following four burns during the period between 1989 and 2006, suggesting that an ideal fire-return interval is no greater than about every four years. However, if drought conditions increase with climate change, this could increase the likelihood of negative fire-drought interactions.

Although their trends were declining, species density, richness, and diversity were still notably greater in the final sample with fire treatment than prior to management. However, in terms of gamma diversity, GCB is back where it started prior to management; in contrast, there has been continuous gradual species attrition at FSB. Increases in ground-layer species richness that occurred through four burns (mean fire-return interval of $4.25 \mathrm{yr}$ ) resulted from enhanced population growth via seedling establishment and vegetative spread of species appropriate for the habitat. Glasgow and Matlack (2007) predicted that frequent fire in the Central Hardwood Region would result in increases among graminoid and opportunist ruderal species. Despite a dynamic rotation of dominant species with fire treatment, increases among ruderal species have not occurred at the study site. Trends for individual species abundance during the 1989 to 1995 estimation period (Taft 2003) were generally a poor predictor for later outcomes, particularly for the increaser species during the early estimation period. Results from this study suggest that gains in species richness during a fire-management program can readily be eroded, particularly gamma diversity. Managers of oak woodland and barrens habitats are faced with difficult choices ranging from the no-treatment option and, gradually, assured loss of habitat characteristics of conservation interest (e.g., native species diversity), versus risks with fire management of negative drought-fire interactions when following recommended fire-return intervals $(\sim 4 \mathrm{yr})$. The practice of infrequent burning (e.g., less than twice per decade) is commonplace (sometimes simply the outcome of poor conditions on scheduled burn dates); however, the infrequent burning may primarily have the effect of provoking the subcanopy without any lasting gains in species diversity or sustainability.

\section{Conclusions}

While similar results might be expected for other dry oak barrens in the region, to assume so risks Type I statistical errors due to the pseudoreplication in the experimental design. Nevertheless, lessons from this study suggest that (1) tree density and eventually basal area can be reduced with persistent fire treatments; (2) ground layer species diversity reliably increases with burning, although negative interactions with droughts are possible; (3) long-term trends for ground-layer diversity may not always keep pace with expectations; and, perhaps of greatest relevance to managers, (4) the shrubsapling stratum can be dynamic and capable of rapid encroachment during prolonged fire-free intervals that can fundamentally alter habitat conditions in oak barrens. From these data, it appears that a fire-return interval of no greater than every four years would be optimal for this oak barrens habitat, achieving management goals of limiting competition from woody overstory while maintaining ground-layer diversity. Given the disagreement between forecasting and long-term outcomes, maintaining monitoring programs for experimental fire treatments is strongly encouraged to enable management decisions to be made with greater confidence. A reduced frequency of data collection can still provide novel insights that can trigger adaptive management.

\section{Supplementary information}

Supplementary information accompanies this paper at https://doi.org/10. 1186/s42408-020-00083-z.

\begin{abstract}
Additional file 1. Tree stratum. Species data from baseline sample (1989) and final sample (2017) for tree stratum (stems $\geq 5 \mathrm{~cm} \mathrm{DBH} \mathrm{ha}{ }^{-1}$ ) at fire-treatment (GCB) and fire-free control (FSB) units of Gibbons Creek Natural Area, Pope County, Illinois, USA. Included are the before-after results and differences by species for tree density, basal area $\left(\mathrm{m}^{2} \mathrm{ha}^{-1}\right)$, and percent importance value ( $\% \mathrm{IV}=$ sum of relative density and relative basal area). Species are shown in descending rank order of the $2017 \%$ IV See Additional file 3 for most nomenclature authorities not found in text. Dash $(-)=$ absent in baseline (1989) sample. Species absent in baseline and final samples appeared during intervening samples.

Additional file 2. Shrub-sapling stratum. Species data from baseline sample (1989) and final sample (2017) for shrub-sapling stratum (stems $\geq$ $50 \mathrm{~cm}$ height, $<5 \mathrm{~cm} \mathrm{DBH}$ ) at fire-treatment (GCB) and fire-free control (FSB) units of Gibbons Creek Natural Area, Pope County, Illinois, USA. Included are the before-after results and differences by species for stem density, frequency, and percent importance value (\% IV = sum of relative density and relative frequency). Species are shown in descending rank order of the $2017 \%$ IV. See Additional file 3 for most nomenclature authorities not found in text. Dash $(-)=$ absent in baseline (1989) sample. Species absent in baseline and final samples appeared during intervening samples.

Additional file 3. Ground-layer stratum. Species data from baseline sample (1989) and final sample (2017) for ground-layer vegetation (herbaceous species and woody plants $<50 \mathrm{~cm}$ in height) at firetreatment (GCB) and fire-free control (FSB) units of Gibbons Creek Natural Area, Pope County, Illinois, USA. Included are the before-after results and differences by species for frequency, percent cover, and percent importance value (\% IV = sum of relative frequency and relative cover). Dash (-) = absent in baseline (1989) sample. Species absent in baseline and final samples appeared during intervening samples. freq. = frequency, cat. = category; estimation period (1989 to 1995) categories (from Taft 2003): A = increasers (\% frequency and cover), $B=$ new species persisting, $C=$ new species non-persisting, $D=$ mixed I (species decreasing or same in frequency, increasing cover), $E=$ mixed II (increase or same frequency, decrease in cover), $F=$ decreasers (frequency and cover), $G=$ extirpated (present at baseline, absent in 1995), $\mathrm{H}=$ no change.
\end{abstract}

\section{Acknowledgements}

Much appreciated field assistance following the initial estimation period was provided by C. Carroll-Cunningham, V. Sivicek, and E. Longo. Thanks also to the US Forest Service and the Illinois Department of Natural Resources, particularly the late B. Lindsay, who was site manager for many years. I am grateful to two anonymous reviewers who provided insightful comments on the manuscript. 


\section{Author's contributions}

JT is responsible for all aspects of the study design, implementation, data management, data analysis, and manuscript development. The author read and approved the final manuscript.

\section{Funding}

Partial support for this study was provided by the Illinois Department of Transportation through a contract with the Illinois Natural History Survey.

\section{Availability of data and materials}

Data sets used for this study are available from the author upon request.

\section{Ethics approval and consent to participate}

Not applicable.

\section{Consent for publication}

Not applicable.

\section{Competing interests}

There are no competing interests in this study.

Received: 26 May 2020 Accepted: 6 September 2020

Published online: 08 October 2020

\section{References}

Abdi, H. 2007. The Bonferroni and Sidak corrections for multiple comparisons. In Encyclopedia of measurement and statistics, ed. N.J. Salkind, 1-9. Thousand Oaks: SAGE Publications, Inc.

Abrams, M.D. 1992. Fire and the development of oak forests. BioScience 42: $346-$ 353. https://doi.org/10.2307/1311781.

Abrams, M.D. 2005. Prescribing fire in eastern oak forests: is time running out? Northern Journal of Applied Forestry 22: 190-196. https://doi.org/10.1093/njaf/ 22.3.190.

Akaike, H. 1973. Information theory as an extension of the maximum likelihood principle. In Proceedings, $2^{\text {nd }}$ International Symposium on Information Theory, ed. B.N. Petrov and F. Caski, 267-281. Budapest: Akademiai Kiado.

Anderson, M.J., R.N. Gorley, and K.R. Clarke. 2008. PERMANOVA+ for PRIMER: Guide to Software and Statistical Methods.

Anderson, R.C. 1983. The eastern prairie-forest transition-an overview. In Proceedings 8th North American prairie conference, ed. R. Brewer, 86-92. Kalamazoo: Western Michigan University.

Anderson, R.C., and J.E. Schwegman. 1991. Twenty years of vegetational change on a southern Illinois barren. Natural Areas Journal 11: 100-107.

Bassett, T.J., D.A. Landis, and L.A. Brudvig. 2020. Effects of experimental prescribed fire and tree thinning on oak savanna understory plant communities and ecosystem structure. Forest Ecology and Management 464 (2020): 118047. https://doi.org/10.1016/j.foreco.2020.118047.

Bowles, M.L., K.A. Jacobs, and J. Mengler. 2007. Long- term changes in an oak forest's woody understory and ground layer with repeated burning. Journal of the Torrey Botanical Society 134: 223-237. https://doi.org/10.3159/10955674(2007)134[223:LCIAOF]2.0.CO;2.

Bowles, M.L., B.A. Lawrence, and D.J. Antlitz. 2017. Thinning effects on canopy structure and ground layer diversity in a burned mesic oak savanna. Journal of the Torrey Botanical Society 144: 191-205. https://doi.org/10.3159/TORREYD-16-00015R1.

Bray, J.R. 1958. The distribution of savanna species in relation to light intensity. Canadian Journal of Botany 36: 671-681. https://doi.org/10.1139/b58-061.

Breshears, D.D. 2006. The grassland-forest continuum: trends in ecosystem properties for woody plant mosaics? Frontiers in Ecology and the Environment 4: 96-104. https://doi.org/10.1890/1540-9295(2006)004[0096:TGCTIE]2.0.CO;2.

Briggs, J.M., A.K. Knapp, J.M. Blair, J.L. Heisller, G.A. Hoch, M.L. Lett, and J.K. McCarron. 2005. An ecosystem in transition: causes and consequences of the conversion of mesic grassland to shrubland. BioScience 55: 243-254. https:// doi.org/10.1641/0006-3568(2005)055[0243:AEITCA]2.0.CO;2.

Brose, P.H., D.C. Dey, and T.A. Waldrop. 2014. The fire-oak literature of eastern North America: synthesis and guidelines. General Technical Report NRS-135. Newtown Square: U.S. Department of Agriculture, Forest Service, Northern Research Station. https://doi.org/10.2737/NRS-GTR-135.

Brose, P.H., T.M. Schuler, and J.S. Ward. 2006. Responses of oak and other hardwood regeneration to prescribed fire: what we know as of 2005. In Fire in eastern oak forests: delivering science to land managers, proceedings of a conference, General Technical Report NRS-P-1, ed. M.B. Dickinson. Newtown Square: U.S. Department of Agriculture, Forest Service, Northern Research Station.

Burton, J.A., S.W. Hallgren, S.D. Fuhlendorf, and D.M. Leslie. 2011. Understory response to varying fire frequencies after 20 years of prescribed burning in an upland oak forest. Plant Ecology 212: 1513-1525. https://doi.org/10.1007/ s11258-011-9926-y.

Collins, S.L., and D.J. Gibson. 1990. effects of fire on community structure in tallgrass and mixed-grass prairie. In Fire in North American Tallgrass Prairies, ed. L.L. Collins and S.L. Wallace, 81-98. Norman: University of Oklahoma Press.

Curtis, J.T. 1959. The Vegetation of Wisconsin. Madison: University of Wisconsin Press.

Daubenmire, R.F. 1959. Plants and Environment: a Textbook of Plant Autecology. New York: John Wiley and sons.

DeSelm, H.R., E.E.C. Clebsch, and J.C. Rennie. 1991. Effects of 27 years of prescribed fire on an oak forest and its soils in Middle Tennessee. In Proceedings Sixth Southern Silvicultural Research Conference, ed. S.S. Coleman and D.G. Neary. Asheville: Report SE-70, Southeastern Forest Experiment Station.

Dey, D.C., and G. Hartman. 2005. Returning fire to Ozark highland forest ecosystems: effects on advance regeneration. Forest Ecology and Management 217: 37-53. https://doi.org/10.1016/j.foreco.2005.05.002.

Dey, D.C., and J.M. Kabrick. 2015. Restoration of midwestern oak woodlands and savannas. In Restoration of Boreal and Temperate Forests, ed. J.A. Stanturf, 2nd ed., 401-428. Boca Raton: CRC Press. https://doi.org/10.1201/b18809.

Flint, R.F. 1928. Natural boundaries in the interior low plateau physiographic province. The Journal of Geology 36: 451-457. https://doi.org/10.1086/623533.

Freund, R.J., and W.J. Wilson. 1993. Statistical Methods. San Diego: Academic.

Glasgow, L.S., and G.R. Matlack. 2007. Prescribed burning and understory composition in a temperate deciduous forest, Ohio, USA. Forest Ecology and Management 238: 54-64. https://doi.org/10.1016/j.foreco.2006.08.344.

Hajny, K.M., D.C. Hartnett, and G.W.T. Wilson. 2011. Rhus glabra response to season and intensity of fire in tallgrass prairie. International Journal of Wildland Fire 20: 709-720. https://doi.org/10.1071/WF09127.

Haney, A., M. Bowles, S. Apfelbaum, E. Lain, and T. Post. 2008. Gradient analysis of an eastern sand savanna's woody vegetation, and its long-term responses to restored fire processes. Forest Ecology and Management 256: 1560-1571. https://doi.org/10.1016/j.foreco.2008.07.004.

Heikens, A., and P. Robertson. 1995. Classification of barrens and other natural xeric forest openings in southern Illinois. Bulletin of the Torrey Botanical Club 122: 203-214. https://doi.org/10.2307/2996085.

Hicks, R.R., Jr. 1998. Ecology and Management of Central Hardwood Forests. New York: Wiley.

Holt, C.E. 1957. Forecasting seasonals and trends by exponentially weighted averages (O.N.R. Memorandum No. 52). Pittsburgh: Carnegie Institute of Technology. https://doi.org/10.1016/j.ijforecast.2003.09.015.

Hulbert, S.H. 1984. Pseudoreplication and the design of ecological field experiments. Ecological Monographs 54: 187-211. https://doi.org/10.2307/1942661.

Hutchinson, T. 2006. Fire and the herbaceous layer of eastern oak forests. In Fire in eastern oak forests: delivering science to land managers, proceedings of a conference, USDA Forest Service General Technical Report NRS-P-1, ed. M.B. Dickinson. Newtown Square: Northern Research Station.

Hutchinson, T.F., R.E. Boerner, S. Sutherland, E. Kennedy Sutherland, M. Ortt, and L. R. Iverson. 2005. Prescribed fire effects on the herbaceous layer of mixed-oak forests. Canadian Journal of Forest Research 35: 877-890. https://doi.org/10. 1139/X04-189.

Hutchison, M.D. 1994. The barrens of the Midwest: an historical perspective. Castanea 59: 195-203.

IBM SPSS 2019. Statistics. Version 26.

Iverson, L.R., T.F. Hutchinson, M.P. Peters, and D.A. Yaussy. 2017. Long-term response of oak-hickory regeneration to partial harvest and repeated fires: influence of light and moisture. Ecosphere 8: 1-24. https://doi.org/10.1002/ ecs2.1642.

Knapp, B.O., M.A. Hullinger, and J.M. Kabrick. 2016. Effects of fire frequency on long-term development of an oak-hickory forest in Missouri, U.S.A. Forest Ecology and Management 387: 19-29. https://doi.org/10.1016/j.foreco.2016.07. 013.

Knapp, B.O., J.M. Marschall, and M.C. Stambaugh. 2017. Effects of long-term prescribed burning on timber value in hardwood forests of the Missouri Ozarks. In Proceedings of the 20th Central Hardwood Forest Conference, USDA 
Forest Service General Technical Report NRS-P-167, ed. J.M. Kabrick, D.C. Dey, B. O. Knapp, D.R. Larsen, S.R. Shifley, and H.E. Stelzer, 304-313. Newtown Square: Northern Research Station.

Leach, M.K., and T.J. Givnish. 1999. Gradients in the composition, structure, and diversity of remnant oak savannas in southern Wisconsin. Ecological Monographs 69: 353-374. https://doi.org/10.1890/0012-9615(1999)069[0353: GITCSA]2.0.CO;2.

Lett, M.S., and A.K. Knapp. 2003. Consequences of shrub expansion in mesic grassland: resource alterations and graminoid responses. Journal of Vegetation Science 14: 487-496. https://doi.org/10.1111/j.1654-1103.2003. tb02175.x.

Matthews, J.W., G. Spyreas, and C.M. Long. 2016. A null model test of floristic quality assessment: are plant species' coefficients of conservatism valid? Ecological Indicators 52: 1-7. https://doi.org/10.1016/j.ecolind.2014.11.017.

Milbauer, M.L., and M.K. Leach. 2007. Influence of species pool, fire history, and woody canopy on plant species density and composition in tallgrass prairie Journal of the Torrey Botanical Society 134: 53-62. https://doi.org/10.3159/ 1095-5674(2007)134[53:iospfh]2.0.co;2.

Mueller-Doombois, D., and H. Ellenberg. 1974. Aims and Methods of Vegetation Ecology. New York: Wiley.

Noss, R.F., E.T. LaRoe III, and J.M. Scott. 1995. Endangered ecosystems of the United States: a preliminary assessment of loss and degradation. U.S. Fish Wildlife Service Biological Report 28 (I-iv): 1-58.

Nowacki, G.J., and M.D. Abrams. 2008. The demise of fire and mesophication of forests in the Eastern United States. BioScience 58: 123-138. https://doi.org/ 10.1641/B580207.

Nuzzo, V.A. 1986. Extent and status of Midwest oak savanna: presettlement and 1985. Natural Areas Journal 6: 6-36.

Peterson, D.W., and P.B. Reich. 2001. Prescribed fire in oak savanna: fire frequency effects on stand structure and dynamics. Ecological Applications 11: 914-927. https://doi.org/10.1890/1051-0761(2001)011[0914:PFIOSF]2.0.CO;2.

Peterson, D.W., and P.B. Reich. 2008. Fire frequency and tree canopy structure influence plant species diversity in a forest-grassland ecotone. Plant Ecology 194: 5-16. https://doi.org/10.1007/s11258-007-9270-4.

Peterson, D.W., P.B. Reich, and K.J. Wrage. 2007. Plant functional group responses to fire frequency and tree canopy cover gradients in oak savannas and woodlands. Journal of Vegetation Science 18: 3-12. https://doi.org/10.1111/j. 1654-1103.2007.tb02510.x.

Rasmussen, P.W., D.M. Heisey, E.V. Nordheim, and T.M. Frost. 1993. Time-series intervention analysis: unreplicated large-scale experiments. In Design and Analysis of Ecological Experiments, ed. S.M. Scheiner and J. Gurevitch, 138-158. New York: Chapman and Hall.

Ratajczak, Z., J.B. Nippert, and T.W. Ocheltree. 2014. Abrupt transition of mesic grassland to shrubland: evidence for thresholds, alternative attractors, and regime shifts. Ecology 95:2633-2645. https://doi.org/10.1890/13-1369.1.

Reed, S.E., J.T. English, R.M. Muzika, J.M. Kabrick, and S. Wright. 2017. Characteristics of sites and trees affected by rapid white oak mortality as reported by forestry professionals. In Proceedings of the 20th Central Hardwood Forest Conference. USDA Forest Service General Technical Report NRS-P-167, ed. J.M. Kabrick, D.C. Dey, B.O. Knapp, D.R. Larsen, S. R. Shifley, and H.E. Stelzer, 240-247. Newtown Square: Northern Research Station.

Refsland, T., and J. Fraterrigo. 2018. Fire increases drought vulnerability of Quercus alba juveniles by altering forest microclimate and nitrogen availability. Functional Ecology 32: 2298-2309. https://doi.org/10.1111/1365-2435.13193.

Rippey, B.R. 2015. The U.S. Drought of 2012. Weather and Climate Extremes 10: 57-64. https://doi.org/10.1016/j.wace.2015.10.004

Scheiner, S.M. 1993. MANOVA: Multivariate response variables and multispecies interactions. In Design and Analysis of Ecological Experiments, ed. S.M. Scheiner and J. Gurevitch, 94-112. New York: Chapman and Hall.

Scholes, R.J., and S.R. Archer. 1997. Tree-grass interactions in savannas. Annual Review of Ecology, Evolution, and Systematics 28: 517-544. https://doi.org/10. 1146/annurev.ecolsys.28.1.517.

Shapiro, S.S., and M.B. Wilk. 1965. An analysis of variance test for normality (complete samples). Biometrika 52: 3-4. https://doi.org/10.2307/2333709.

Stewart-Oaten, A., W.W. Murdoch, and K.R. Parker. 1986. Environmental impact assessment: "pseudoreplication" in time? Ecology 67: 929-940. https://doi.org/ 10.2307/1939815

Taft, J.B. 1997. Savanna and open-woodland communities. In Conservation in Highly Fragmented Landscapes, ed. M.W. Schwartz, 24-54. Chicago: Chapman and Hall. https://doi.org/10.1007/978-1-4757-0656-7_2.
Taft, J.B. 2003. Fire effects on community structure, composition, and diversity in a dry sandstone barrens. Journal of the Torrey Botanical Society 130: 170-192. https://doi.org/10.2307/3557552.

Taft, J.B. 2009. Effects of overstory stand density and fire on ground layer vegetation in oak woodland and savanna habitats. In Proceedings of the 3 rd Fire in Eastern Oak Forests Conference. USDA Forest Service General Technical Report NRS-P-46, ed. T.F. Hutchinson, 21-37. Newtown Square: Northern Research Station.

Taft, J.B., C. Carroll-Cunningham, Z.P. Kron, and H.L. Grant. 2019. Can a mesic grassland mosaic recover from thicketization? Insights from seven years monitoring species abundance. Ecological Restoration 37: 8-24. https://doi. org/10.3368/er.37.1.8.

Taft, J.B., C. Hauser, and K.R. Robertson. 2006. Estimating floristic integrity in tallgrass prairie. Biological Conservation 131: 42-51. https://doi.org/10.1016/j. biocon.2006.02.006

Taft, J.B., and Z.P. Kron. 2014. Evidence of species and functional group attrition in shrub-encroached prairie: implications for restoration. American Midland Naturalist 172: 252-265. https://doi.org/10.1674/0003-0031-172.2.252.

Taft, J.B., and M.K. Solecki. 2002. Vegetation composition, structure, and diversity patterns of two dry sandstone barrens in southern Illinois. Castanea 67: 343-368.

Taft, J.B., G.S. Wilhelm, D.M. Ladd, and L.A. Masters. 1997. Floristic Quality Assessment for vegetation in Illinois, a method for assessing vegetation integrity. Erigenia 15: 3-95.

Tester, J.R. 1989. Effects of fire frequency on oak savanna in east-central Minnesota. Bulletin of the Torrey Botanical Society 116: 134-144. https://doi. org/10.2307/2997196.

van Mantgem, P., J.C.B. Nesmith, M. Keifer, E.E. Knapp, A. Flint, and L. Flint. 2013. Climatic stress increases forest fire severity across the western United States. Ecology Letters 16: 1151-1156. https://doi.org/10.1111/ele.12151.

van Mantgem, P., M. Schwartz, and M. Keifer. 2001. Monitoring fire effects for managed burns and wild fires: coming to terms with pseudoreplication. Natural Areas Journal 21: 266-273 http://www.naturalareas.org/docs/v21_3_01.

Vander Yacht, A.L., S.A. Barrioz, P.D. Keyser, C.A. Harper, D.S. Buckley, D.A. Buehler, and R.D. Applegate. 2017. Vegetation response to canopy disturbance and season of burn during oak woodland and savanna restoration in Tennessee. Forest Ecology and Management 390: 187-202. https://doi.org/10.1016/j. foreco.2017.01.029.

von Ende, C.N. 1993. Repeated-measures analysis: growth and other timedependent measures. In Design and Analysis of Ecological Experiments, ed. S. M. Scheiner and J. Gurevitch, 113-137. New York: Chapman and Hall.

White, A.S. 1983. The effects of thirteen years of annual prescribed burning on a Quercus ellipsoidalis community in Minnesota. Ecology 64: 1081-1085. https://doi.org/10.2307/1937817.

Whittaker, R.H. 1975. Communities and Ecosystems. New York: MacMillan Publishing Company Inc..

Wood, J.D., B.O. Knapp, R.M. Muzika, M.C. Stambaugh, and L. Gu. 2018. The importance of drought - pathogen interactions in driving oak mortality events in the Ozark Border Region. Environmental Research Letters 13: 015004. https://doi.org/10.1088/1748-9326/aa94fa.

\section{Publisher's Note}

Springer Nature remains neutral with regard to jurisdictional claims in published maps and institutional affiliations.

\section{Submit your manuscript to a SpringerOpen ${ }^{\circ}$ journal and benefit from:}

- Convenient online submission

- Rigorous peer review

- Open access: articles freely available online

High visibility within the field

- Retaining the copyright to your article

Submit your next manuscript at $\boldsymbol{\sim}$ springeropen.com 